\title{
PENGARUH ETIKA BISNIS, FAKTOR KONTINGENSI DAN TINGKAT PENGGUNAAN INTERNET TERHADAP DAYA SAING
}

\author{
Zainurrafiqi \\ Zainur_rafiqi@yahoo.co.id \\ Ria Rachmawati \\ Fakultas Ekonomi Universitas Madura
}

\begin{abstract}
ABSTRAK
This study aims to make Micro, Small and Medium Enterprises in Pamekasan Regency able to increase the contribution of Gross Regional Domestic Product (GRDP) per capita in Pamekasan Regency, export volume as the instrument of income distribution, reducing inequality of welfare and opening of new jobs. To be able to compete in the free market, MSME must have superior competitiveness by implementing internet in their business, with full support from top management. to realize the creation of competitiveness is needed. To find out the extent of role Business Ethics, Contingency Factors and Level of Internet Usage in improving competitiveness, hypothesis testing are carried out. The data collected by using questionnaire, with the Convenience Sampling Method. The questionnaire was distributed to 400 MSME Managers in Pamekasan Regency as a sample. Data analysis uses the Structural Equation Model program. The result shows contingency factor has a positive effect on the level of internet adoption. Level of Internet adoption has a positive effect on competitiveness. Business Ethics has a positive effect on Competitiveness, and demographic variables have different effects on Business Ethics, contingency factors, the level of Internet adoption and competitivenes.
\end{abstract}

Key words: business ethics, contingency factors, level of internet adoption, competitiveness.

\begin{abstract}
ABSTRAK
Penelitian ini bertujuan agar Usaha Mikro Kecil Menengah (UMKM) di Kabupaten Pamekasan mampu meningkatkan kontribusi Produk Domestik Regional Bruto (PDRB) perkapita Kabupaten Pamekasan, volume ekspor serta menjadi instrumen pemerataan pendapatan, mengurangi ketimpangan kesejahteraan dan terbukanya lapangan kerja baru. Untuk bisa bersaing di pasar bebas, UMKM herus memiliki daya saing yang unggul dengan cara mengimplementasikan internet dalam bisnis mereka, serta adanya dukungan penuh dari manajemen puncak, untuk mewujudkan terciptanya daya saing juga diperlukan. Untuk mengetahui sejauh mana peran Etika Bisnis, Faktor Kontingensi dan Tingkat Penggunaan Internet dalam meningkatkan daya saing maka dilakukan dengan pengujian hipotesis. Pengumpulan data menggunakan kuesioner, dengan Metode Sampling Convenience, kuesioner dibagikan kepada 400 Pengelola UMKM dikabupaten Pamekasan sebagai sampel. Analisis data menggunakan program Structural Equation Model. Hasilnya yaitu Faktor Kontingensi berpengaruh positif terhadap Tingkat Penggunaan Internet. Tingkat Penggunaan Internet berpengaruh positif terhadap Daya Saing, Etika Bisnis berpengaruh positif terhadap Daya Saing, dan variabel demografi memiliki pengaruh berbeda terhadap Etika Bisnis, faktor kontingensi, tingkat penggunaan Internet dan daya saing.
\end{abstract}

Kata kunci: etika bisnis, faktor kantingensi, tingkat penggunaan internet, daya saing.

\section{PENDAHULUAN}

Keberadaan UMKM terkadang dikaitkan dengan problematika ekonomi dan Sosial seperti kemiskinan, distribusi pen- dapatan, pemerataan pembangunan dan urbanisasi. Harapannya UMKM dapat berkontribusi untuk mengurangi problematika tersebut. UMKM dianggap sebagai back bone 
perekonomian nasional dengan alasan 99 persen mendominasi sebagai pelaku usaha, menghasilkan Produk Domestik Bruto 59 persen dengan tingkat pertumbuhan sebesar 6,4 persen dalam setiap tahun, volume ekspor sebesar 14 persen dari total ekspor nasional. Keberadaan UMKM me- nyebar dibanyak sektor, keberadaan UMKM juga memberikan multiplier effect yang tinggi, dan dianggap sebagai alat ukur pemerataan pendapatan dan kesejahteraan masyarakat. (Kementerian Koperasi dan UMKM, 2014).

UMKM memiliki peran krusial dalam perekonomian Indonesia, seperti menyediakan lapangan kerja yang cukup besar, perannya dalam mengembangkan kegiatan ekonomi lokal dan pemberdayaan masyarakat cukup signifikan; menciptakan market baru serta sebagai wadah inovasi dan kreatifitas, dengan kegiatan ekspornya dapat menjaga keseimbangan neraca pembayaran, sehingga diperlukan awareness yang tinggi untuk mengembangkan UMKM khususnya di Kabupaten Pamekasan demi terwujudnya kesejahteraan masyarakat Madura secara umum.

Faktanya keberadaan UMKM khususnya di Pamekasan masih belum maksimal dalam mewujudkan perannya tersebut. Ada dua kendala yang dialami oleh pelaku UMKM, yaitu eksternal dan internal berkaitan dengan minimnya pengetahuan SDM terkait perkembangan teknologi produksi yang terbaru serta lemahnya quality control terkait produk, teknik pemasaran yang masih tradisional dengan mengandalkan metode pemasaran dari mulut ke mulut dirasa kurang maksimal, padahal saat ini sudah tersedia media sosial dan jaringan internet seperti facebook dan lain-lain sebagai sarana pemasaran produk terkadang pemilik masih mengalami permasalahan teknis, sehingga kurang memperhatikan rencana strategis jangka panjang bisnisnya. Adapun kendala yang dihadapi berkaitan dengan Akuntabilitas yang kurang baik seperti, manajemen perusahaan dan keuangan, Sedangkan dari sisi eksternal kendala yang dihadapi terkait dengan akses, seperti, akses terhadap bahan baku yang kurang memadai sehingga bahan baku yang berkualitas rendahlah yang diperoleh para pelaku usaha UMKM tersebut. Kendala lain yang dihadapi seperti belum terpenuhinya minat konsumen yang sering berubah, para pelaku usaha UMKM yang terjun kepasar ekspor belum mampu bersaing dengan perusahaan yang mampu memanfaatkan kecanggihan tehnologi dalam kegiatan pemasaran. (Badan Pusat Statistik Kabupaten Pamekasan, 2010-2014).

UMKM harus memiliki strategi pemasaran yang unik untuk memenangkan persaingan dalam dunia bisnis. Untuk mampu bersaing, sektor UMKM membutuhkan strategi yang tepat agar mampu memperoleh keuntungan jangka panjang (Chamsuk et al. (2015). Daya saing adalah kunci utama dalam bidang manajemen strategi dan bisnis ekonomi. Daya saing dianggap sebagai faktor yang sangat penting dalam mendapatkan peluang. Peluang yang besar dan tujuan organsasi perlu untuk ditawarkan agar sektor UMKM mampu memperoleh keuntungan secara terus menerus dari pada pesaingnya. Dalam bisnis, persaingan adalah sumber untuk meningkatkan posisi perusahaan dimana hal tersebut dapat dianggap sebagai keuntungan ekonomi yang dicapai, serta menghadapi konsekuensi terhadap pesaingnya yang berfokus pada produksi seperti dari segi kualitas produk, biaya produksi dan harga. Tidak hanya itu, untuk meningkatkan daya saing maka diperlukan strategi. Ada beberapa faktor yang dapat mempengaruhi daya saing yang pertama adalah Etika Bisnis (Kasasbeh et al., 2014), yang kedua adalah Faktor Kontingensi (Teo dan Pian, 2003) dan yang ketiga adalah Penggunaan Teknologi (Tian et al., 2010), ketiga faktor tersebut merupakan implementasi yang tepat dalam strategi bisnis perusahaan sebagai salah satu usaha untuk memenangkan persaingan.

Konsep Etika Bisnis sangat di perlukan untuk diterapkan dalam dunia bisnis, penerapan etika bisnis merupakan suatu kebutuhan dalam dunia kerja. Di negara- 
negara besar konsep etika dihubungkan oleh berbagai subjek dan berbagai macam kegiatan organisasi, energi dan sumber daya manusia, contohnya adalah para manajer, karyawan, manajemen perusahaan dan tenaga penjual yang harus mencerminkan suatu etika yang baik, dalam dunia kerja. Konsep ini menjadi hal yang baik untuk suatu perusahaan. Terkait perilaku seseorang ditempat kerja, etika dapat menjadi pembeda antara mana yang baik dan yang buruk sehingga etika berperan sebagai sensor dari individu, karyawan yang memiliki etika yang tinggi ketika bekerja dalam suatu organisasi dapat menularkan etika tersebut pada karyawan lainnya. (Chang, 2011)

Terkadang pertumbuhan perusahaan dilatar belakangi dengan adanya kasus skandal, pelanggaran, penyuapan, penyelewengan. Adanya etika dan standarisasi yang jelas diperlukan masyarakat untuk menentukan hubungan antara bisnis dan masyarakat serta menentukan hubungan antara perusahaan dengan karyawan dan konsumen. Adanya kesadaran terkait pentingnya etika bisnis menandakan terjadinya pergeseran akan pendapat publik tentang organisasi serta tanggung jawab etis lembaga yang diharapkan mampu memperoleh profitabilitas bagi pemegang saham dengan memproduksi produk dan jasa dengan harga yang sesuai norma yang berlaku dimasyarakat sekitar, serta sesuai aturan yang berlaku secara umum. Perusahaan harus memperhatikan tanggung jawabnya terkait etika bisnis dalam aspek lingkungan, produk, ras, gender, dan standar keselamatan masyarakat dalam lingkungan kerja (Kasasbeh et al., 2014).

Faktor Kontingensi dalam kaitannya dengan penggunaan internet di anggap sebagai faktor internal dan eksternal yang berkaitan dengan posisi resiko manajemen puncak, kebijakan tehnologi, serta support manajemen puncak. Adanya dukungan manajemen puncak terkait kompatibilitas teknologi sangat diperlukan untuk menghadapi intensitas persaingan dan intensitas informasi. Organisasi berperan semakin maksimal dengan aplikasi internet dibandingkan aspek lingkungan (Teo dan Pian, 2003). Sebagai manfaat dari perdagangan elektonik memahami cost leader lebih bermanfaat bagi perusahaan dari pada hanya mengiterpretasikan perbedaan. Organisasi bisnis menggunakan sistem informasi untuk bisa terkoneksi dengan konsumen bahkan dengan pesaing, yang dampaknya perusahaan bisa mendapatkan manfaat strategis dengan banyak mengetahui tentang pesaingnya. Perusahaan elektronik seringkali menghadapi persoalan terkait keseimbangan otoritas dengan hubungan mitra bisnis. Untuk memperkenalkan efisiensi seluruh kegiatan perusahaan sehari-hari maka perusahaan besar tersebut melakukan pertukaran data elektronik. Selain itu, agar dapat mempengaruhi rantai pasokan serta dapat mempertahankan posisi dominannya, perusahaan tersebut melakukan peningkatan ukuran perusahaan mereka (Lai et al., 2006).

Perusahaan kecil dipaksa untuk melakukan pertukaran data elektronik oleh para pelaku usaha besar. Faktor penting untuk penerapan tehnologi baru adalah meniru proses dan komunikasi dari para pesaing industri. Hasil tehnologi didasarkan pada penerapan serta penerimaan dari pihak-pihak yang terkait. Adapun hasil yang diperoleh pertama kali pada saat penerapan selalu dipengaruhi oleh waktu keputusan penerapan. Apabila perusahaan lain tersebut tidak langsung menirukan inovasi tersebut maka akan bermanfaat bagi sipengguna awal. Manfaat dari penerapan teknologi tersebut adalah sebagai tolak ukur standarisasi perusahaan atau bahkan apakah lebih layak teknologi substitusi, secara singkat dapat dijelaskan bahwa penerapan internet dipengaruhi oleh beberapa faktor kontingensi serta berpengaruh secara luas terhadap perusahaan. Akan tetapi, tidak semua faktor kontingensi berdampak signifikan. Demikian juga, efek penerapan internet tidak sama antara perusahaan (Teo dan Pian, 2003).

Adanya gap diatas terkait peran Tingkat 
Penggunaan Internet, Faktor Kontingensi dan Etika Bisnis terhadap Daya Saing UMKM secara kusus dan untuk perusahaan pada umumnya menjadi alasan krusial untuk diteliti, utamanya UMKM di Kabupaten Pamekasan. Tujuan penelitian ini yaitu untuk mengeksplorasi serta menganalisis peran Tingkat Penggunaan Internet, Faktor Kontingensi dan Etika Bisnis sebagai faktor yang mempengaruhi daya saing UMKM. Harapannya penelitian ini berkontribusi positif terhadap Masyarakat dan Pemerintah.

\section{TINJAUAN TEORETIS}

\section{Tingkat Penggunaan Internet}

Teo dan Pian (2003) beberapa penelitian merekomendasikan terkait jenis atau tingkat penggunaan internet yang tidak sama. Satu penelitian merekomendasikan model proses tiga tingkat. Adapun untuk tingkat pertama yaitu visibilitas, artinya pada level ini perusahaan berusaha mewakili proses kegiatan fisik yang lebih efektif melalui teknologi informasi. Level yang kedua disebut dengan istilah mencerminkan kemampuan. Perusahaan pada level kedua ini menggantikan operasi virtual untuk yang fisik, dan pada level yang ketiga yaitu di istilahkan dengan hubungan pelanggan baru, pada level ini perusahaan memberikan value terhadap pelanggannya dengan cara yang terbaru. Adapun metode lain memperhatikan jenis kegiatan usaha yang dilengkapi dengan teknologi internet.

Selanjutnya, Penggunaan internet dapat dibagi menjadi tiga level: level yang pertama yaitu akses informasi, level yang kedua yaitu kolaborasi kerja dan level yang ketiga yaitu transaksi bisnis inti.

\section{Faktor Kontingensi dan Tingkat Pengguna- an Internet}

Level penggunaan internet bermacammacan, sehinnga, sangat menarik untuk meneliti beberapa variabel kontingensi yang berpengaruh signifikan terhadap level Penggunaan Internet. Alasan dipilihnya variabel ini karena studi terdahulu menyimpulkan bahwa penggunaan internet berpengaruh secara signifikan (Teo dan Pian, 2003).

Strategi teknologi bisnis.

Pengertian Strategi Teknologi Bisnis merujuk kepada kecepatan perusahaan dalam mengikuti adanya inovasi teknologi, dengan penjelasan yang lain perusahaan selalu berusaha untuk up-to-date terkait peralatan, inovasi produk, dan teknologi produksi (Swimm dan Andriole, 2010).

\section{Dukungan manajemen puncak.}

Bisnis didunia digital menjadi semakin besar selain adanya penggunaan internet juga dibutuhkan adanya dukungan seorang manajer yang berkaitan dengan penggunaan internet, dimana hal itu merupakan bagian dari keputusan strategi bisnis. Oleh karena alasan tersebut, support manajemen puncak memiliki peluang terbesar dan faktor terpenting berkaitan dengan level penggunaan internet, serta dapat meningkatkan teknologi informasi yang dapat menjadikan perusahaan lebih sukses (Ahmed dan Mohamad, 2016).

\section{Kompatibilitas Teknologi.}

Penerapan tekonologi baru bisa terhambat jika terdapat kontradiksi dengan nilai-nilai perusahaan dan aturan kerja. Organisasi menganggap penggunaan tekno logi internet relatif mudah. Namun, penggunaan internet pada level lebih tinggi kemungkinan kesatupaduan yang lebih baik dari teknologi dengan konteks bisnis, yang pada akhirnya memfokuskan pada pentingnya kompatibilitas teknologi (Hernandez et al., 2008).Berdasarkan uraian diatas maka hipotesisi yang pertama yaitu:

$\mathrm{H}_{1}$ : Faktor Kontingensi berpengaruh positif terhadap Tingkat Penggunaan Internet.

\section{Tingkat Penggunaan Internet dan Daya Saing.}

Perusahaan memakai internet untuk berbagai macam alasan. Menurut Hazen dan Byrd (2012) sebagian perusahaan menganggap pemakian Internet hanya dianggap 
sebagai sesuatu yang sederhana sementara untuk perusahaan yang lain pemakaian internet dipergunakan dengan tujuan integrasi bisnis atau transformasi bisnis. Perusahaan dengan level pemakaian internet yang berbeda berpengaruh terhadap daya saing yang dihasilkan. Teo dan Pian (2003) terdapat lima strategi yang direkomendasikan mampu meningkatkan daya saing perusahaan. yaitu persekutuan, inovasi, pertumbuhan, pengurangan biaya dan diferensiasi. Berikut uiraian terkait peran penggunaan Internet terhadap daya saing.

\section{Persekutuan}

Kannabiran (2012) Teknologi imformasi dan Internet dapat mewujudkan huhungan baru antara bisnis serta dapat memperluas ruang lingkup industri, dan perusahaan harus bersaing dalam rangka meningkatkan daya saing. Untuk memperkokoh serta mempertahankan kerjasama yang sukses, maka komunikasi antara mitra memiliki peran yang sangat penting.

\section{Inovasi}

Raymond dan Bergeron (2008) dampak inovasi yaitu jaringan produk yang semakin meluas, baik terkait jaringan rantai nilai, jaringan industri, proses penelitian dan pengembangan, penjualan, pembelian dan transportasi bahan baku, kontrol kualitas, pembuatan suku cadang dan komponen, pemasaran, pengujian, perakitan, distribusi grosir, dan ritel.

\section{Pertumbuhan}

Raymond dan Bergeron (2008) Pemakaian internet bisa membantu perusahaan untuk memperluas pasar serta pelanggannya, sehingga dapat membantu metode atau cara perkembangan bisnis. Pemakaian teknologi internet dapat berdampak pada kapabilitas perkembangan bisnis dengan cara memperluas ruang lingkup dan usaha inti melewati market penetration dan product development. Dengan internet, perusahaan dapat dengan lebih cepat serta lebih efektif dalam memperluas market sharenya bahkan secara inter- nasional. Dan juga, penggunaan teknologi internet bisa memberi peluang pasar baru serta saluran distribusi baru.

\section{Pengurangan biaya.}

Huang et al.(2010) studi mengenai bisnis elektronik menemukan bahwa penerapan pasar digital mampu mengurangi biaya transaksi. Dan juga, teknologi informasi dan internet bisa meminimalisir biaya untuk pengolahan, memperoleh dan transmisi informasi, sehingga mampu mengubah metode perusahaan dalam menerapkan perdagangannya.

\section{Diferensiasi}

Simmons et al. (2007) adanya pasar digital dapat memberikan kontribusi bagi perusahaan lainnya terkait harga dan inovasi produk dan pelayanan yang lebih baik kepada pelanggan serta kebih cepat terjun ke pasar. Dan juga, pemakaian internet bisa membantu perusahaan dalam menyediakan produk serta pelayanan yang terbaik serta disesuaikan dengan selera pelanggan, tentunya hal tersebut mampu meningkatkan profit diferensiasi. Ditopang oleh diskusi kelompok, dan masyarakat pelanggan, formulir pendaftaran,e-mail dan fitur interaktivitas Internet, perusahaan bisa memperoleh data pelanggan dengan cepat, seperti permintaan potensi produk atau jasa, komentar produk dan demografi. Merujuk pada penjelasan di atas maka hipotesis selanjutnya yaitu:

$\mathrm{H}_{2}$ : Tingkat Penggunaan Internet berpengaruh positif terhadap Daya Saing.

\section{Etika Bisnis dan Daya Saing}

Etos kerja merupakan bagian penting dari framework yang dapat mengorganisasikan behavior dan attitude terhadap sesuatu, serta mampu mendeskripsikan terhadap hal baik atau buruk, salah atau benar seperti kebiasaan atau adat dan hukum,dalam hal ini sistem, nilai, budaya organisasi dan stakeholder memiliki peran penting dalam menentukan standarisasi dari hal tersebut (Kasasbeh et al., 2014) 
Taleb (2015) bahwa kesadaran tanggung jawab etika kusus dalam suatu perdagangan adalah tidak terikat dengan kewajiban hukum dan lingkungan, pemilik dan karyawan secara bersama-sama miliki tanggung jawab yang sana dalam mewujudkan tujuan perusahaan. secara bersama-sama bekerja dengan sepenuh hati untuk kepuasan pelanggan mereka dan masyarakat pada umumnya, dan sebagai hasil dari semua itu adalah dapat meningkatkan keuntungan, dan hal tersebut adalah bagian dari tujuan perusahaan. Berdasarkan uraian di atas, maka hipotesis ketiga dalam penelitian ini adalah sebagai berikut:

$\mathrm{H}_{3}$ : Etika Bisnis berpengaruh positif terhadap Daya Saing.

Hubungan antara variabel demografi dengan Faktor Kontingensi, Tingkat Penggunaan Internet, Etika Bisnis dan Daya Saing.

Penelitian Terdahulu
Dalam rangka untuk mempelajari hubungan antara Faktor Kontingensi, Tingkat Penggunaan Internet, Etika Bisnis dan Daya Saing secara lebih mendalam, penelitian ini menganalisis pengaruh pada hubungan ini dari beberapa variabel internal dan eksternal: jenis UMKM, tingkat pendidikan pemilik UMKM, usia pemilik UMKM, jenis kelamin pemilik UMKM, tingkat pendapatan dari UMKM danjangka waktu beroprasinya UMKM.

Menurut Jiménez-Jiménez dan SanzValle (2011) ada pengaruh positif antara ukuran, usia, industri dan lingkungan turbulensi antara Faktor Kontingensi, Tingkat Penggunaan Internet, Etika Bisnis dan Daya Saing. Penelitian ini membuat hipotesis sebagai berikut:

$\mathrm{H}_{4}$ : Variabel demografi berpengaruh signifikan terhadap Faktor Kontingensi, Tingkat Penggunaan Internet, Etika Bisnis dan Daya Saing.

\section{Tabel 1}

Penelitian terdahulu

\begin{tabular}{ll}
\hline Nama/tahun & Judul \\
\hline Kearns dan & Sumberdaya Berbasis \\
Lederer & Keselarasan Strategi TI: \\
$(2003)$ & Bagaimana Berbagi \\
& Pengetahuan Mencipta \\
& kan daya saing
\end{tabular}

Teo dan Sebuah perspektif konti Pian, (2003) ngensi terkait penggunaan Internet dan Daya saing

Chen et al. Pengaruh Kinerja (2006) Green Innovation terhadap laba Perusahaan di Taiwan

Chen (2008) Pengaruh Positif Green Intellectual Capital terhadap daya saing Per-

\section{Hasil}

Kehadiran teknologi informasi berpengaruh signifikan terhadap kesuksesan penerapan strategi Teknilogi Iinformasi itu sendiri. Jadi harmonisasi antara strategi teknologi informasi dengan rencana bisnis secara signifikan memiliki peran penting dalam penggunaan teknologi informasi demi menciptakan daya saing.

Strategi teknologi bisnis telah ditemukan berpengaruh positif dengan tingkat adopsi internet. kompatibilitas teknologi dan dukungan manajemen puncak ditemukan tidak berpengaruh signifikan dengan tingkat adopsi internet. Selanjutnya, tingkat adopsi Internet berpengaruh signifikan terhadap daya saing.

Green process innovation dan green product innovation berpengaruh signifikan terhadap daya saing.

Green relational capital, green structural capital dan green human capital berpengaruh signifikan terhadap daya saing. 


\begin{tabular}{|c|c|}
\hline & \\
\hline $\begin{array}{l}\text { Torabito et } \\
\text { (2010) }\end{array}$ & $\begin{array}{l}\text { Survei terhadap sistem } \\
\text { informasi terpadu dan } \\
\text { daya saing }\end{array}$ \\
\hline $\begin{array}{l}\text { Tian et al., } \\
\text { (2010) }\end{array}$ & $\begin{array}{l}\text { Kemampuan penyeba- } \\
\text { ran TI terhadap daya } \\
\text { saing: Sebuah studi } \\
\text { eksplorasi di Cina }\end{array}$ \\
\hline (2011) & $\begin{array}{l}\text { Pengaruh Etika Ling- } \\
\text { kungan perusahaan } \\
\text { terhadap daya saing: } \\
\text { sebuah Mediasi Peran } \\
\text { Green Innovation }\end{array}$ \\
\hline dan & Tanggung Jawab Sosial \\
\hline $\begin{array}{l}\text { Arshad } \\
(2012)\end{array}$ & $\begin{array}{l}\text { Perusahaan atau CSR } \\
\text { sebagai sumber daya } \\
\text { saing: Peran mediasi } \\
\text { social capital dan repu- } \\
\text { tational capital }\end{array}$ \\
\hline $\begin{array}{l}\text { Kasasbeh et } \\
\text { al. (2014) }\end{array}$ & $\begin{array}{l}\text { Dampak Etika Bisnis } \\
\text { terhadap daya saing } \\
\text { (Dalam kegiatan Per- } \\
\text { usahaan Komunikasi } \\
\text { Seluler Di Yordania) }\end{array}$ \\
\hline
\end{tabular}

Chamsuk et Penelitian Dan Peal. (2015) ngembangan Kemampuan Dan Kemampuan Inovasi dalam Mempengaruhi daya saing

Taleb (2015) Sebuah Kerangka Berbagi Pengetahuan, Kemampuan Inovasi Perusahaan dan daya saing di Uni Emirat
Sebagian besar perusahaan belum menggunakan sistem informasi integrasi dengan sumber daya organisasi yang tepat. Daya saing tidak muncul dari sumber yang mudah ditiru.

Hasil penelitian ini memberikan dukungan untuk hubungan antara kemampuan penyebaran TI dan daya saing.

Etika lingkungan perusahaan berpengaruh signifikan terhadap green process innovation dan green product innovation. Dan green product innovation memediasi hubungan positif antara etika lingkungan perusahaan dan daya saing,

Strategi Coroporate social responsibility yang diterapkan oleh suatu perusahaan dapat menciptakan daya saing dan pada akhirnya dapat meningkatkan laba perusahaan.

Hasil penelitian menunjukkan etika bisnis (independensi dan objektivitas, kejujuran, integritas, keadilan dan transparansi) berpengaruh signifikan untuk mencapai daya saing (pengurangan biaya, inovasi dan pembaharuan) dalam perusahaan komunikasi seluler yang beroperasi di Yordania..

bahwa kekampuan inovasi berpengaruh signifikan terhadap daya saing perusahaan.

bahwa Berbagi Pengetahuan, Kemampuan Inovasi Perusahaan berpengaruh signifikan terhadap daya saing perusahaan.

\section{Arab \\ Sumber: Data Penelitian Terdahulu}

Berdasarkan penelitian terdahulu pada Tabel 1, terdapat empat belas konsep sebagai dimensi yang mempengaruhi Daya saing. Taleb (2015) menggunakan Kemampuan Inovasi Perusahaan dan Berbagi Pengetahuan. Kearns dan Lederer (2003) menggunakan Strategi Penerapan Informasi Teknologi Terintegrasi. Chen et al., (2006),
Green Innovation Performance. Saeed dan Arshad, (2012), Tanggung Jawab Sosial Perusahaan. Kasasbeh et al., (2014), Etika Bisnis. Tian et al., (2010) Kemampuan Penyebaran Informasi Teknologi. Morabito et al., (2010), Sistem Informasi Terpadu (SIT). Chang, (2011), Etika Lingkungan Perusahaan. Chen (2008), Green Intellectual Capital. 
Chamsuk et al., (2015), Kemampuan Penelitian dan Pengembangan Dan Kemampuan Inovasi, Teo dan Pian (2003), Faktor Kontingensi, Level Penggunaan Internet

Diantara konsep Tingkat Penggunaan Internet, Etika Bisnis dan Faktor Kontingensi, belum pernah dilakukan studi sebelumnya yang secara bersamaan menggunakan ketiga konsep tersebut terkait perannya terhadap daya saing UMKM di indonesia pada khususnya. Studi terdahulu hanya berfokus pada salah satu diantara tiga konsep tersebut, sehingga hal tersebut berdampak pada hasil penelitian serta rekomendasi yang diberikan, yang tentunya hanya memberikan gambaran terkait salah satu dari ketiga konsep tersebut dalam kaitannya dengan daya saing, akan tetapi berbeda dengan penelitian yang dilakukan ini yang telah mengintegrasikan ketiga konsep tersebut sebagai sebuah kerangka penelitian, tujuannya adalah untuk memperoleh informasi yang lebih lengkap serta kontribusi penelitian yang lebih mendalam terkait peran dari Tingkat Penggunaan Internet, Etika Bisnis dan Faktor Kontingensi terhadap Daya Saing.

\section{METODE PENELITIAN \\ Rerangka Penelitian}

Gambar 1 menunjukkan hubungan antara konsep dan hipotesis penelitian yang didasarkan pada teori dan penelitian terdahulu.

\section{Skala Pengukuran}

Pengukuran Variabel menggunakan skala Likert dengan rentang 1 sampai 7 . angka 1 artinya "Sangat Tidak Setuju" sedangkan angka 7 artinya 7 "Sangat Setuju". yang terdiri dari variabel eksogen dan variabel endogen. Adapun variabel eksogen terdiri dari tiga konsep yaitu Tingkat Penggunaan Internet, Etika Bisnis dan Faktor Kontingensi, Sedangkan, variabel endogennya adalah Daya Saing.

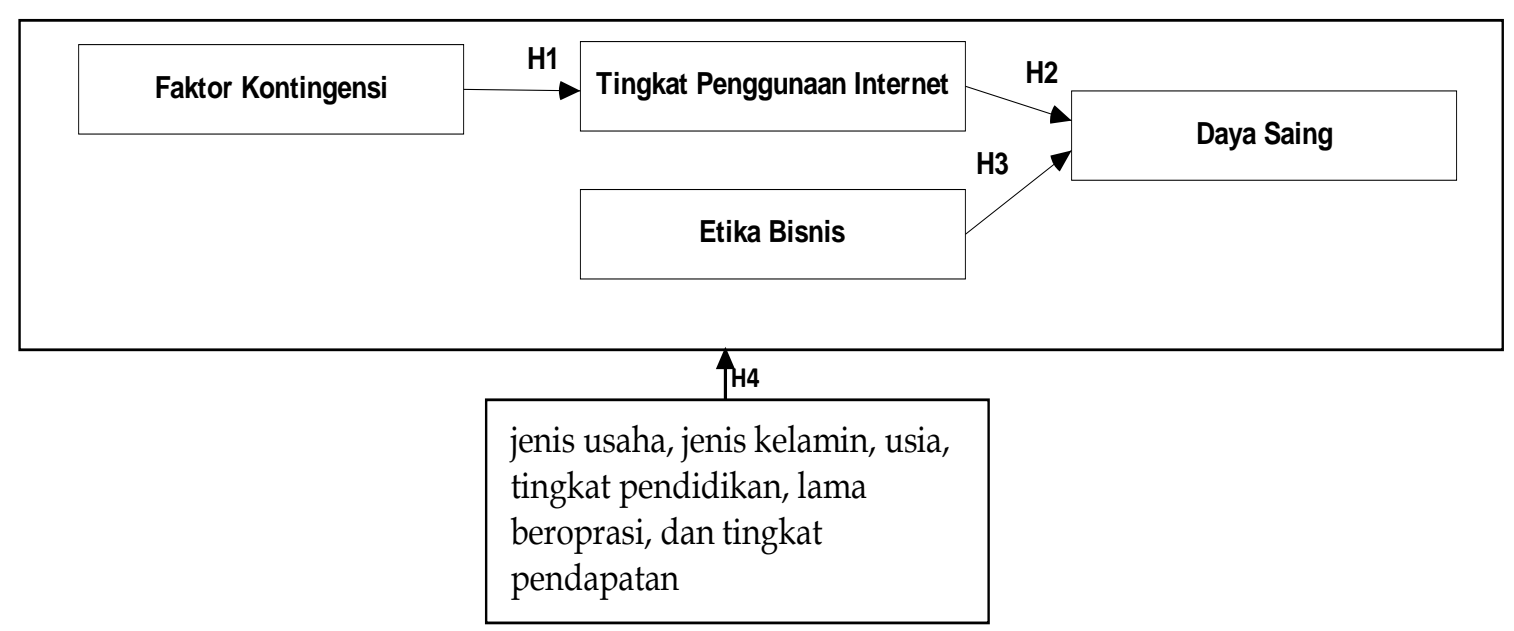

Gambar 1

Rerangka penelitian

\section{Jenis Penelitian}

Penelitian ini termasuk kategori eksplanatory research. Peneliti menguji dengan menentukan hipotesis dan pengumpulan data untuk mendukung atau menolak hipotesis.

\section{Objek Penelitian}

Penelitian ini dilakukan di Kabupaten Pamekasan. Kabupaten Pamekasan merupakan salah satu pusat bisnis di wilayah Madura yang layak diperhitungkan dan memiliki komitmen untuk meningkatkan Daya Saing bisnis di pasar Nasional dan Internasional. Kabupaten Pamekasan terbagi menjadi tiga belas kecamatan yaitu Pasean, 
Batumarmar, Waru, Pakong, Kadur, Pegantenan, Palengaan, Proppo, Pamekasan, Larangan, Galis, Pademawu dan Tlanakan. Menurut Bentler dan Chou (1987) distribusi normal ukuran sampel untuk sejumlah parameter bebas minimal 5: 1 , sehingga ukuran sampel penelitian ini adalah 76 * $5=$ 380 responden. Dalam rangka untuk memastikan keandalan data, penelitian ini akan menyebarkan 400 kuesioner kepada para manajer UMKM di Kabupaten Pamekasan.

\section{Metode Pengumpulan Data}

Penelitian ini bersumber pada data Primer. Pendekatan wawancara pribadi digunakan untuk mendapatkan data dari pemilik atau pengelola UMKM. Peneliti meng- gunakan kuesioner untuk mendapatkan informasi dengan berhadapan langsung dengan pemilik atau manajer UMKM di Kabupaten Pamekasan, diajukannya pertanyaan yang mendalam untuk memperoleh data dan informasi yang sesuai dengan masalah yang sedang diselidiki.

\section{Teknik Analisis Data}

Penelitian ini menggunakan SEM untuk menyelidiki hubungan linear antara variabel, pengujian hipotesis dan hubungan kausal antara variabel menggunakan AMOS 17 software. Menurut Hooper et al. (2008) dan MacCallum et al. (1996) persyaratan yang harus dipenuhi dalam SEM bisa dilihat pada Tabel 2.

Tabel 2

The Standard Estimation of Overall Model Fit

\begin{tabular}{ll}
\hline Index & Standard of Estimation \\
\hline Absolute Fit Indices & \\
Chi-squire (X2/df) & $\leq 2$ \\
Goodness of Fit (GFI) & $\geq 0.9$ \\
Adjusted Goodness of Fit (AGFI) & $\geq 0.9$ \\
Root Mean Square Error of Approximation (RMSEA) & $\leq 0.05$ \\
Root Mean Square of Residual (RMR) & $\leq 0.05$ \\
Incremental Fit Indices & $\geq 0.9$ \\
Normed fit index (NFI) & $\geq 0.9$ \\
Non-normed Fit Index (NNFI) & $\geq 0.9$ \\
Comparative fit index (CFI) & $\geq 0.05$ \\
Parsimony Fit Indices & $\geq 0.05$ \\
Parsimonious Goodness of Fit Index (PGFI) & \\
Parsimonious Normed Fit Index (PNFI) & \\
\hline
\end{tabular}

\section{ANALISIS DAN PEMBAHASAN}

Analisis data menggunakan sofware AMOS 17 dengan metode Structural Equation Model (SEM). Terdapat dua tahapan dalam Structural Equation Model (SEM). Tahap yang pertama yaitu Measurement Model dan tahapan yang kedua yaitu Stuctural Model (Kaplan, 2000)

a. Measurement Model

Goodness Fit Indices

Penghitungan Measurement Model yakni dengan menggunakan metode Confirmatory
Factor Analysis (CFA). Persyaratan dalam Penghitungan Goodness Fit Indices yakni merujuk kepada beberapa poin sebagai berikut, yang pertama adalah nilai Chi-square (x2), yang kedua yaitu Goodness of Fit (GFI), yang ketika yaitu Adjusted Goodness of Fit (AGFI), yang ke empat yaitu Root Mean Square Error of Approximation (RMSEA), yang kelima yaitu Comparative fit index (CFI), dan indikator lainnya yang secara keseluruhan termasuk dalam penghitungan measurement model fit indices. (Hooper et 
al., 2008). Berdasarkan Table 3 diperoleh hasil sebagai berikut yaitu $\chi^{2} / \mathrm{df}$-ratio adalah 2,76 yaitu berada pada interval 3 yang artinya model telah memenuhi kriteria sehingga model bisa di terima. Adapun terkait penilaian terhadap GFI, NFI, NNFI, dan CFI yaitu diperoleh nilai lebih besar dari atau mendekati 0,9 , hal tersebut bermakna bahwa penghitungan terkait GFI, NFI, NNFI, dan CFI sudah memenuhi kriteria persyararan model sehingga dapat disimpulkan model dapat diterima.

Tabel 3

The Measurement Model Fit Result

\begin{tabular}{ll}
\hline \hline Index & Result \\
\hline Chi-squire $\left(\chi^{2}\right)$ & 439.280 \\
Chi-squire DF & 159 \\
Chi-squire (X2/df) & 2.76 \\
Goodness of Fit (GFI) & 0.94 \\
Adjusted Goodness of Fit (AGFI) & 0.88 \\
Root Mean Square Error of Approximation (RMSEA) & 0.09 \\
Root Mean Square of Residual (RMR) & 0.01 \\
Normed fit index (NFI) & 0.92 \\
Non-normed Fit Index (NNFI) & 0.95 \\
Comparative fit index (CFI) & 0.98 \\
\hline
\end{tabular}

\section{Sumber : data hasil penelitian (diolah)}

Adapun terkait penghitungan RMSEA diperoleh nilai sebesar 0,09, sehingga dapat disimpulkan nilai tersebut masih bisa diterima karena menurut MacCallum et al. (1996) ring nilai untuk RMSEA adalah diantara 0,05 sampai fengan 0,10 adalah bisa diterima. Jadi Pengukuran secara keseluruhan telah memenuhi standarisasi penilaian pada measurement model fit indices.

\section{Uji Validitas dan Reabilitas pada Measure- ment model}

Pengujian reabilitas pada pada penelitian ini sudah memenuhi kriteria persyaratan standarisasi terkait pengujian variabel. Variabel pada penelitian ini di uji menggunakan Standardized Loading dan Composite Reliability. Penghitungan Composite Reliability terdapat pada Tabel 4 yang diperoleh nilai antara 0,8. Fornell \& Larcker (1981), nilai Composite Reliability dapat diterima jika lebih besar dari 0,60.

Pengujian Validitas pada penelitian ini yaitu menggunakan Confirmatory Factor Analysis dalam rangka untuk mengukur nilai Convergent Validity. Tabel 4 menyajikan informasi sebagai berikut, yang pertama adalah nilai $\mathrm{t}$-value, yang kedua adalah terkait nilai Standardized Loading, dan berdasarkan penghitungan pada tabel 4 maka dapat disimpulkan bahwa untuk semua variabel pada penelitian ini adalah signifikan yakni diperoleh nilai yang lebih besar dari 1,96 , hal tersebut membuktikan bahwa path coefficient pada penelitian tersebut adalah signifikan, sehingga dapat disimpulkan bahwa semua indikator pada penelitian ini telah memenuhi standarisasi persyaratan penghitungan Convergent Validity (Anderson dan Gerbing, 1988).

\section{Discriminant validity}

Pengujian discriminant validity bertujuan untuk menilai korelasi antar variabel dengan cara membandingkannya, kriteria pengambilan keputusannya yaitu semakin tinggi correlation coefficient antara dua variabel adalah tanda bahwa pengujian discriminant validity tidak dapat memenuhi kriteria standarisasi persyaratan diterimanya model penelitian.

Adapun untuk pengujian discriminant validity pada penelitian ini dengan memilih "Tingkat Penggunaan Internet" dan "Daya 
Saing", "Etika Bisnis" dan "Daya Saing", dengan nilai correlation coefficient yaitu 0,75 dan 0,71 , dengan p-value $<0,001$, hal tersebut dilakukan untuk membuktikan bahwa dua pasang variabel tersebut mempunyai discriminant validity.

Tabel 4

Scale Composite Reliability and Convergent Validity Analysis

\begin{tabular}{lcccc}
\hline \hline \multicolumn{1}{c}{$\begin{array}{c}\text { Construct (F) and } \\
\text { Indicators (V) }\end{array}$} & $\begin{array}{c}\text { Standardized } \\
\text { Loading }\end{array}$ & t value & $\begin{array}{c}\text { Indicator } \\
\text { Reliability }\end{array}$ & $\begin{array}{c}\text { Composite } \\
\text { Reliability }\end{array}$ \\
\hline Faktor Kontingensi (F1) & & & & \\
V1 Strategi teknologi bisnis & 0,83 & 19,96 & 0,67 & 0,87 \\
V2 Dukungan manajemen puncak & 0,89 & 22.24 & 0.79 & \\
V3 Kompatibilitas Teknologi & 0.82 & 19.77 & 0.66 & \\
Tingkat Penggunaan Internet (F2) & & & & \\
V4 Level 0 - adopsi e-mail & 0.92 & 22.72 & 0.90 & \\
V5 Level 1 - Kehadiran Internet & 0.93 & 22.74 & 0.93 & \\
V6 Level 2 - Pencarian & 0.88 & 19.29 & 0.74 & \\
V7 Level 3 - integrasi bisnis & 0.97 & 24.83 & 0.96 & \\
V8 Level 4 - transformasi bisnis & 0.99 & 26.57 & 0.99 & \\
Etika Bisnis (F3) & & & & \\
V9 Independensi dan objektivitas & 0.91 & 22.71 & 0.88 & \\
V10 Kerahasiaan dan kejujuran & 0.87 & 22.27 & 0.72 & \\
V11 Transparansi dan Integritas. & 0.80 & 19.20 & 0.63 & \\
V12 Pengurangan Biaya & 0.95 & 24.78 & 0.92 & \\
V13 Inovasi dan pembaharuan & 0.98 & 26.47 & 0.95 & \\
Daya Saing (F4) & & & & \\
V14 Diferensiasi & 0.91 & 22.71 & 0.88 & \\
V15 Pengurangan biaya. & 0.87 & 22.27 & 0.72 & \\
V16 Inovasi & 0.88 & 19.29 & 0.74 & 0,93 \\
V17 Pertumbuhan & 0,89 & 22.24 & 0.79 & \\
V18 Persekutuan & 0.99 & 26.57 & 0.99 & \\
\hline
\end{tabular}

Sumber : data hasil penelitian (diolah)

Tabel 5

Discriminant Validity Analysis

\begin{tabular}{lcccccc}
\hline & $\begin{array}{c}\text { Correlation } \\
\text { Coefficient }\end{array}$ & \multicolumn{1}{c}{$\begin{array}{c}\text { Unidimensional } \\
\text { Measurement } \\
\text { Model }\end{array}$} & $\begin{array}{c}\text { Measurement } \\
\text { Model }\end{array}$ & $\begin{array}{c}\text { The } \\
\text { difference }\end{array}$ & P value \\
\hline $\begin{array}{l}\text { Etika Bisnis } \leftrightarrow \\
\text { Daya Saing }\end{array}$ & $0.71^{* * *}$ & $\begin{array}{l}\text { Chi- } \\
\text { square }\end{array}$ & 998.95 & 429,37 & 569,58 & $<0.001$ \\
DF & 151 & 150 & 1 & $<0.001$ \\
$\begin{array}{l}\text { Tingkat } \\
\begin{array}{l}\text { Penggunaan } \\
\text { Internet } \leftrightarrow \\
\text { Daya Saing }\end{array}\end{array}$ & $0.75^{* * *}$ & $\begin{array}{l}\text { square } \\
\text { sF }\end{array}$ & 640.39 & 430.34 & 210.05 & $<$ \\
\hline
\end{tabular}

Sumber : data hasil penelitian (diolah)

*** $\mathbf{p}<0.001$.

Berdasarkan hasil pengujian yang disajikan pada Tabel 5 dapat dijelaskan bahwa nilai chi-square berbeda dan serta pengujian terkait unidimensional measurement model 
untuk 1 pasang menunjukkan nilai yang signifikan. Hal itu dapat dikatakan bahwa veriabel-variabel tersebut berbeda. Secara umum, semua pengujian telah menunjukkan bahwa discriminant validity telah memenuhi standarisasi persyaratan diterimanya model penelitian, hal itu ditunjukkan dengan nilai korelasi terbesar antar variabel adalah berbeda secara signifikan.

\section{b. Model Struktural (Structural Model)}

Penelitian ini menyajikan penelitian empirik tentang faktor-faktor yang mempengaruhi Keunggulan Kompetitif. Secara keseluruhan hasil pngujian untuk goodness fit of structural model bisa dilihat pada Tabel 6 Nilai Chi-square $\left(x^{2}\right) /$ df-ratio yaitu 2,74 menurut Schumacker dan Lomax (2004) normal diterimanya ring nilai untuk chi-square yaitu antara nilai 1 sampai 3, sedangkan untuk nilai GFI dan nilai NNFI juga bisa diterima karena lebih besar dari 0,8 dan mendekati
0,9. RMSEA masih diterima karena nilainya sama dengan atau kurang dari 0,1. secara keseluruhan persyaratan terkait goodness fit indices of structural model pada Model struktural telah diterima. Penilaian untuk Model structural RNFI yaitu harus lebih besar dari nilai 0,9 , atau mendekati nilai 1 adalah lebih baik. Adapun pengujian terkait RPR adalah untuk mengetahui nilai structural models terhadap parsimony degree. Penilaiannya yaitu antara nilai 0,0 sampai dengan nilai 1,0, Jadi penilaian pengambilan kesimpulannya yaitu semakin besar semakin baik goodness of fit nya. RPFI sangat berguna untuk memilih model yang secara simultan memaksimumkan fit and parsimony pada structural portion of the model. Dengan nilai RPFI yang lebih tinggi maka lebih diperlukan. Hal itu dapat dilihat pada Tabel 6 RNFI $=0.96$, of RPR $=0,37$, and RPFI $=0,35$, model struktural ini menunjukkan goodness of fit and parsimony.

Tabel 6

Structural Model Goodness Fit Indices

\begin{tabular}{lllllllllllll}
\hline \multicolumn{1}{c}{ Combined Model } & \multicolumn{4}{c}{ Structural Model } \\
\hline Chi- square & DF & X2/df & GFI & AGFI & CFI & NFI & NNFI & RMR & RMSEA & RNFI & RPR & RPFI \\
& & & & & & & & & & & & \\
490.990 & 179 & 2.74 & 0.87 & 0.86 & 0.91 & 0.88 & 0.89 & 0.04 & 0.09 & $\mathbf{0 . 9 6}$ & $\mathbf{0 . 3 7}$ & $\mathbf{0 . 3 5}$ \\
\hline
\end{tabular}

Sumber : data hasil penelitian (diolah).

\section{Hasil uji hipotesis}

Tabel 7 menyajikan informasi terkait hasil dari pengujian hipotesis, sedangkan Gambar 2 menyajikan informasi terkait nilai dari path analisis, adapun penjelasannya sebagai berikut yakni sebagai berikut. Pada Tabel 3 diperoleh hasil koefisien jalur terkait pengaruh Etika Bisnis terhadap Daya Saing yaitu 0,39, dan pengaruh Tingkat Penggunaan Internet terhadap Daya Saing yaitu 0,48 dan yang terakhir yaitu pengaruh Faktor Kontingensi terhadap Tingkat Penggunaan Internet yaitu 0.99. Selanjutnya pembahasan mengenai, Daya Saing dan Tingkat Penggunaan Internet sebagai variabel dependen, maka dipetoleh nilai r2 untuk Daya Saing yaitu 0,63 , sedangkan nilai r2 untuk Tingkat Penggunaan Internet yaitu 0,92. adapun kriteria penilaian terkait pengaruh $\mathrm{r} 2$ yaitu 0.02 artinya pengaruhnta kecil, 0.13 artinya pengaruhnya sedang dan 0.26 artinya pengaruhnya besar (Kleijnen, et al., 2007). Simpulannya adalah Daya Saing dan Tingkat Penggunaan Internet adalah memiliki pengaruh yang besar karena nilainya diatas 0.26 . Hasil analisis path bisa dilihat pada Tabel 7.

\section{Analisis Varians}

Analisis varians meliputi t-test, ANOVA, dan Scheffe test. Penelitian ini menggunakan analisis t-test terkait jenis kelamin untuk menguji adanya perbedaan di antara masing-masing variabel laten yang diamati, yaitu Faktor Kontingensi, Tingkat Penggunaan Internet, Etika Bisnis, Daya Saing. 
Tabel 7

Structural Model Path Coefficient

\begin{tabular}{llccc}
\hline \multicolumn{1}{c}{$\begin{array}{c}\text { Dependent } \\
\text { Variable }\end{array}$} & \multicolumn{1}{c}{$\begin{array}{c}\text { Independent } \\
\text { Variable }\end{array}$} & $\begin{array}{c}\text { Standardized } \\
\text { path coefficient }\end{array}$ & t value & $\begin{array}{c}\text { Square Multiple } \\
\text { Correlation ( r2) }\end{array}$ \\
\hline Daya saing & $\begin{array}{l}\text { Etika Bisnis } \\
\text { Tingkat Pengguna- } \\
\text { an Internet }\end{array}$ & 0,39 & $7.80^{*}$ & \\
& $\begin{array}{l}\text { Faktor Kontingen- } \\
\text { si }\end{array}$ & 0,98 & $11.20^{*}$ & 0,63 \\
$\begin{array}{l}\text { Tingkat Penggunaan } \\
\text { Internet }\end{array}$ & & $25.60^{*}$ & 0,92 \\
\hline si & & &
\end{tabular}

Sumber : data hasil penelitian (diolah).

${ }^{*} \mathrm{p}<0.001$.

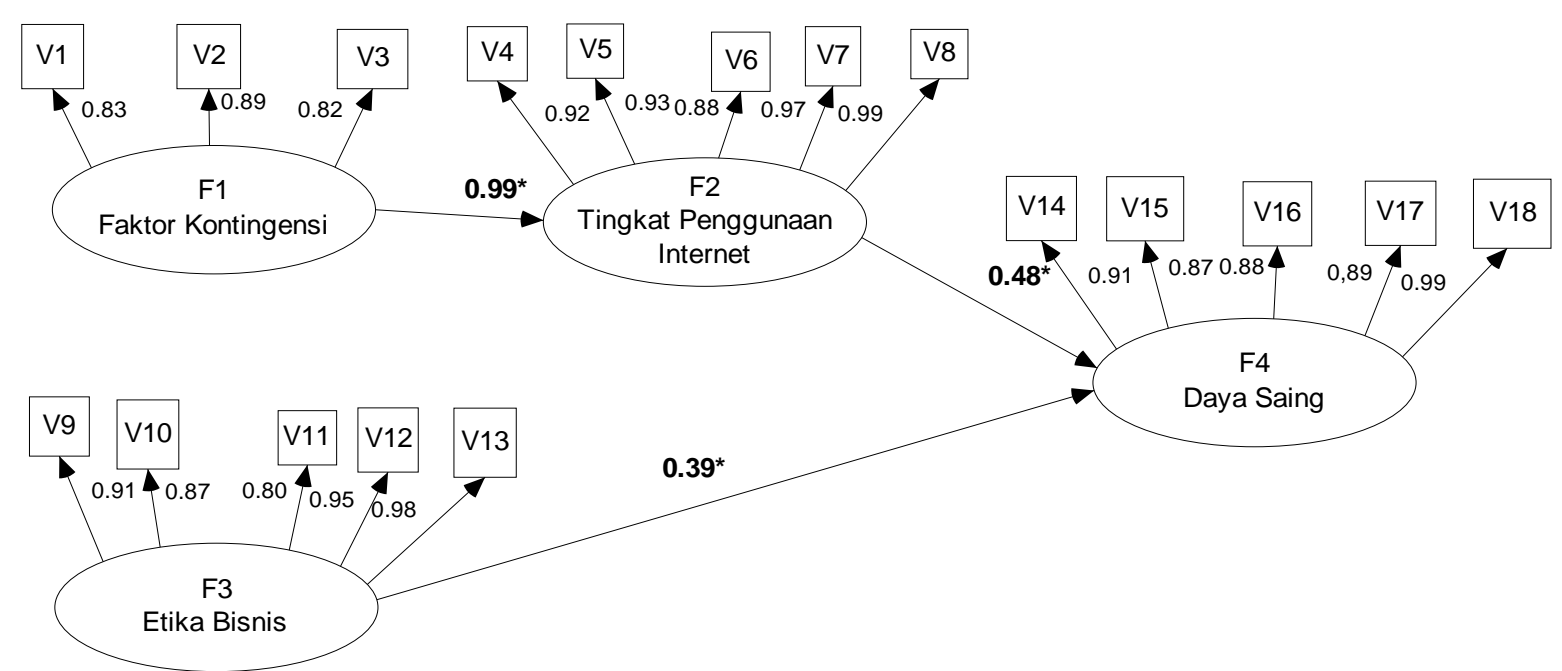

\section{Gambar 2 \\ Standar path koefiseien \\ Hasil Penelitian}

Analisis ANOVA terdiri dari umur pengusaha, tingkat pendidikan, Rentang Waktu menjalankan UMKM, dan tingkat pendapatan UMKM. ANOVA menguji perbedaan pengaruh variabel demografis terhadap masing-masing variabel laten yang diamati. Selanjutnya Scheffe test digunakan setelah analisis perbedaan varians. Berdasarkan analisis perbedaan varians, dapat diketahui daftar kelompok yang memiliki perbedaan yang signifikan.

\section{Analisis Varians Jenis kelamin}

Uji Jenis kelamin menggunakan analisis t-test karena hanya memiliki dua kelompok perbedaan, pria dan wanita. Analisis ini bertujuan untuk mengetahui ada tidaknya ciri yang berbeda dalam jenis kelamin untuk setiap variabel. Tabel 8 menunjukkan hasil uji Jenis kelamin. Hasilnya menunjukkan ada perbedaan signifikan antara pria dan wanita yaitu pada indikator Strategi teknologi bisnis pada variabel Faktor Kontingensi, indikator Level 3 - integrasi bisnis dan Level 4 - transformasi bisnis pada variabel Tingkat Penggunaan Internet, indikator Kerahasiaan dan kejujuran pada variabel Etika Bisnis dan Indikator Inovasi pada variabel Daya Saing dengan $t$ value lebih besar dari 1,96 dan $\mathrm{P}$ value dibawah 0,05 . Hal tersebut menunjukkan bahwa hubungan antara jenis kelamin pria dan wanita manajer UMKM tidaklah sama dalam UMKM dan hal itu tampak pada perbedaan itu tampak pada pengaruh yang signifikan terhadap masing-masing variabel laten. 
Tabel 8

Analisis t-test untuk Jenis kelamin

\begin{tabular}{|c|c|c|c|c|c|c|}
\hline \multirow{2}{*}{ Variabel } & \multirow{2}{*}{$\begin{array}{c}\text { Nama } \\
\text { Kode }\end{array}$} & \multirow{2}{*}{ Indikator } & \multicolumn{2}{|c|}{ Jenis kelamin } & \multirow{2}{*}{$\begin{array}{c}t \\
\text { Value }\end{array}$} & \multirow{2}{*}{ P Value } \\
\hline & & & Laki-laki & Perempuan & & \\
\hline \multirow{4}{*}{$\begin{array}{c}\text { Faktor } \\
\text { Kontingensi }\end{array}$} & V1 & $\begin{array}{l}\text { Strategi teknologi } \\
\text { bisnis }\end{array}$ & 4.38 & 4.27 & 2.23 & $0.02^{*}$ \\
\hline & V2 & $\begin{array}{l}\text { Dukungan } \\
\text { manajemen puncak }\end{array}$ & 5.32 & 5.28 & 1.24 & 0.53 \\
\hline & V3 & $\begin{array}{l}\text { Kompatibilitas } \\
\text { Teknologi }\end{array}$ & 5.84 & 5.89 & 1.53 & 0.67 \\
\hline & V4 & $\begin{array}{l}\text { Level } 0 \text { - adopsi e- } \\
\text { mail }\end{array}$ & 3.30 & 3.05 & 1.16 & 0.68 \\
\hline \multirow{4}{*}{$\begin{array}{l}\text { Tingkat } \\
\text { Penggunaan } \\
\text { Internet }\end{array}$} & V5 & $\begin{array}{l}\text { Level } 1 \text { - Kehadiran } \\
\text { Internet }\end{array}$ & 2.67 & 2.58 & 1.04 & 0.83 \\
\hline & V6 & Level 2 - Pencarian & 4.40 & 4.30 & 1.32 & 0.72 \\
\hline & V7 & $\begin{array}{l}\text { Level } 3 \text { - integrasi } \\
\text { bisnis }\end{array}$ & 4.21 & 4.19 & 2.37 & $0.01^{* *}$ \\
\hline & V8 & $\begin{array}{l}\text { Level } 4 \text { - transformasi } \\
\text { bisnis }\end{array}$ & 5.32 & 5.28 & 2.04 & $0.02^{*}$ \\
\hline \multirow{7}{*}{ Etika Bisnis } & V9 & $\begin{array}{l}\text { Independensi dan } \\
\text { objektivitas }\end{array}$ & 5.47 & 5.44 & 1.02 & 0.31 \\
\hline & V10 & $\begin{array}{l}\text { Kerahasiaan dan } \\
\text { kejujuran }\end{array}$ & 5.40 & 5.40 & 2.38 & $0.01^{* *}$ \\
\hline & V11 & $\begin{array}{l}\text { Transparansi dan } \\
\text { Integritas. }\end{array}$ & 5.41 & 5.39 & 1.09 & 0.19 \\
\hline & V12 & Pengurangan Biaya & 4.65 & 4.59 & 1.22 & 0.44 \\
\hline & V13 & $\begin{array}{l}\text { Inovasi dan } \\
\text { pembaharuan }\end{array}$ & 4.75 & 4.56 & 1.33 & 0.72 \\
\hline & V14 & Diferensiasi & 4.62 & 4.59 & 1.08 & 0.47 \\
\hline & V15 & Pengurangan biaya. & 5.32 & 5.28 & 1.23 & 0.38 \\
\hline \multirow{3}{*}{ Daya Saing } & V16 & Inovasi & 4.34 & 429 & 2.25 & $0.02^{*}$ \\
\hline & V17 & Pertumbuhan & 4.23 & 4.20 & 1.37 & 0.58 \\
\hline & V18 & Persekutuan & 4.41 & 4.37 & 1.28 & 0.76 \\
\hline
\end{tabular}

Sumber : data hasil penelitian (diolah).

\section{Analisis Varians Jenis UMKM}

Dalam penelitian ini jenis UMKM terbagi dalam tiga kategori yaitu makanan, fashion, dan kerajinan. Uji ANOVA terhadap jenis UMKM menunjukkan bahwa sebagian variabel dengan indikator signifikan. Hasil uji Scheffe menunjukkan bahwa semua indikator dari variabel Faktor Kontingensi adalah signifikan, dengan rincian tipe fashion lebih tinggi daripada jenis kerajinan, dan jenis kerajinan lebih tinggi daripada jenis makanan dan ada dua indikator dari Tingkat Penggunaan Internet signifikan yaitu Level 0 adopsi e-mail dan Level 1 Kehadiran Internet, dengan rincian tipe fashion lebih tinggi daripada jenis kerajinan, dan jenis kerajinan lebih tinggi daripada jenis makanan. dan juga ada dua indikator dari Etika Bisnis signifikan yaitu Independensi dan objektivitas, dengan rician tipe fashion lebih tinggi daripada jenis kerajinan dan jenis makanan, Kerahasiaan dan kejujuran, dengan rincian tipe fashion lebih tinggi daripada jenis kerajinan, dan jenis kerajinan lebih tinggi daripada jenis makanan. Hasilnya bisa dilihat pada Tabel 9.

\section{Analisis Varians Usia Manajer UMKM}

Tabel 10 menunjukkan ada perbedaan yang signifikan pada indikator Kompatibilitas Teknologi dengan perbandingan kelompok umur dengan rentang 41-50 tahun 
lebih tinggi daripada di atas 50 tahun. Dan umur 31-40 tahun ini lebih tinggi daripada umur di atas 50 tahun. Dan juga ada perbedaan yang signifikan pada indikator Level 0 - adopsi e-mail yaitu umur $\leq 30$ lebih tinggi daripada umur di atas 50 tahun. Dan juga ada perbedaan yang signifikan pada indikator Level 1 Kehadiran Internet yaitu umur
31-40 lebih tinggi daripada umur di atas 50 tahun. Dan juga ada perbedaan yang signifikan pada indikator Persekutuan yaitu umur $\leq 30$ lebih tinggi daripada umur 31-40, 41-50 dan umur di atas 50 tahun. Selanjutnya hasilnya lebih banyak dapat dilihat pada Tabel 10.

Tabel 9

Hasil tes ANOVA untuk Jenis UMKM

\begin{tabular}{|c|c|c|c|c|c|c|c|c|}
\hline \multirow[b]{2}{*}{ Variable } & \multirow{2}{*}{$\begin{array}{l}\text { Code } \\
\text { Name }\end{array}$} & \multirow[b]{2}{*}{ Indicators } & \multicolumn{3}{|c|}{ Rata-rata tipe UMKM } & \multirow[b]{2}{*}{$\begin{array}{c}F \\
\text { Value }\end{array}$} & \multirow[b]{2}{*}{ P Value } & \multirow{2}{*}{$\begin{array}{c}\text { Scheff } \\
\text { e's } \\
\text { Test }\end{array}$} \\
\hline & & & $\begin{array}{c}\text { Makan } \\
\text { an (1) }\end{array}$ & $\begin{array}{l}\text { Fashio } \\
\text { n (2) }\end{array}$ & $\begin{array}{l}\text { Kerajin } \\
\text { an (3) }\end{array}$ & & & \\
\hline \multirow{4}{*}{$\begin{array}{l}\text { Faktor } \\
\text { Kontingensi }\end{array}$} & V1 & $\begin{array}{l}\text { Strategi teknologi } \\
\text { bisnis }\end{array}$ & 5.18 & 5.60 & 5.45 & $\underset{* * *}{23.36}$ & $<.0001$ & $\begin{array}{l}2>1 \\
3>1\end{array}$ \\
\hline & V2 & $\begin{array}{l}\text { Dukungan } \\
\text { manajemen puncak }\end{array}$ & 4.19 & 4.42 & 4.56 & $\begin{array}{c}20.26 \\
* * *\end{array}$ & $<.0001$ & $\begin{array}{l}3>1 \\
2>1\end{array}$ \\
\hline & V3 & $\begin{array}{l}\text { Kompatibilitas } \\
\text { Teknologi }\end{array}$ & 5.86 & 6.00 & 5.81 & $3.26^{*}$ & 0.04 & $2>3$ \\
\hline & V4 & $\begin{array}{l}\text { Level } 0 \text { - adopsi e- } \\
\text { mail }\end{array}$ & 2.73 & 4.00 & 3.72 & $\begin{array}{c}47.42 \\
* * *\end{array}$ & $<.0001$ & $\begin{array}{l}2>1 \\
3>1\end{array}$ \\
\hline \multirow{4}{*}{$\begin{array}{l}\text { Tingkat } \\
\text { Penggunaan } \\
\text { Internet }\end{array}$} & V5 & $\begin{array}{l}\text { Level } 1 \text { - Kehadiran } \\
\text { Internet }\end{array}$ & 2.35 & 3.37 & 2.84 & $\begin{array}{c}34.00 \\
* * *\end{array}$ & $<.0001$ & $\begin{array}{l}2>3 \\
2>1 \\
3>1\end{array}$ \\
\hline & V6 & Level 2 - Pencarian & 5.46 & 5.35 & 5.3 & 2.07 & 0.11 & - \\
\hline & V7 & $\begin{array}{l}\text { Level } 3 \text { - integrasi } \\
\text { bisnis }\end{array}$ & 4.50 & 4.36 & 4.29 & 1.01 & 0.39 & - \\
\hline & V8 & $\begin{array}{l}\text { Level } 4 \text { - } \\
\text { transformasi bisnis }\end{array}$ & 4.32 & 4.28 & 4.21 & 2.04 & 0.27 & - \\
\hline \multirow{6}{*}{ Etika Bisnis } & V9 & $\begin{array}{l}\text { Independensi dan } \\
\text { objektivitas }\end{array}$ & 4.57 & 4.88 & 4.57 & $\begin{array}{c}5.74^{*} \\
*\end{array}$ & 0.004 & $\begin{array}{l}2>1 \\
2>3\end{array}$ \\
\hline & V10 & $\begin{array}{l}\text { Kerahasiaan dan } \\
\text { kejujuran }\end{array}$ & 4.26 & 4.55 & 4.58 & $\begin{array}{c}19.57 \\
* * *\end{array}$ & $<.0001$ & $\begin{array}{l}3>1 \\
2>1\end{array}$ \\
\hline & V11 & $\begin{array}{l}\text { Transparansi dan } \\
\text { Integritas. }\end{array}$ & 4.88 & 4.54 & 4.67 & 2.39 & 0.07 & - \\
\hline & V12 & Pengurangan Biaya & 5.39 & 5.30 & 5.21 & 1.96 & 0.14 & - \\
\hline & V13 & $\begin{array}{l}\text { Inovasi dan } \\
\text { pembaharuan }\end{array}$ & & & & & 0.31 & - \\
\hline & V14 & Diferensiasi & 2.77 & 2.60 & 2.40 & 2.09 & 0.13 & - \\
\hline \multirow{4}{*}{ Daya Saing } & V15 & $\begin{array}{l}\text { Pengurangan } \\
\text { biaya. }\end{array}$ & 5.54 & 5.42 & 5.45 & 0.84 & 0.43 & - \\
\hline & V16 & Inovasi & 5.80 & 5.94 & 6.00 & $2.61^{*}$ & 0.04 & - \\
\hline & V17 & Pertumbuhan & 4.37 & 4.31 & 4.44 & 1.18 & 0.33 & - \\
\hline & V18 & Persekutuan & 4.26 & 4.20 & 4.32 & 1.37 & 0.51 & - \\
\hline
\end{tabular}

Sumber : data hasil penelitian (diolah).

* $\mathrm{a}<0.05,{ }^{* *} \mathrm{a}<0.01, * * * \mathrm{\alpha}<0.001$. 
Tabel 10

Hasil ANOVA untuk Umur manajer UMKM

\begin{tabular}{|c|c|c|c|c|c|c|c|c|c|}
\hline \multirow{2}{*}{ Variable } & \multirow{2}{*}{$\begin{array}{l}\text { Code } \\
\text { Name }\end{array}$} & \multirow{2}{*}{ Indicators } & \multicolumn{4}{|c|}{$\begin{array}{c}\text { umur } \\
\text { (dalam tahun) }\end{array}$} & \multirow{2}{*}{$\begin{array}{c}\text { F } \\
\text { Value }\end{array}$} & \multirow{2}{*}{$\begin{array}{c}P \\
\text { Value }\end{array}$} & \multirow{2}{*}{$\begin{array}{c}\text { Schef } \\
\text { fe's } \\
\text { Test }\end{array}$} \\
\hline & & & $\begin{array}{c}\leq 30 \\
1\end{array}$ & $\begin{array}{c}31-40 \\
2\end{array}$ & $\begin{array}{c}41-50 \\
3\end{array}$ & $\begin{array}{c}\geq 50 \\
4\end{array}$ & & & \\
\hline \multirow{4}{*}{$\begin{array}{c}\text { Faktor } \\
\text { Kontingensi }\end{array}$} & V1 & Strategi teknologi bisnis & 5.46 & 5.35 & 5.3 & 5.16 & 2.07 & 0.11 & - \\
\hline & V2 & $\begin{array}{l}\text { Dukungan manajemen } \\
\text { puncak }\end{array}$ & 4.50 & 4.36 & 4.29 & 4.28 & 1.01 & 0.39 & - \\
\hline & V3 & Kompatibilitas Teknologi & 5.88 & 5.86 & 5.93 & 5.63 & $5.26^{* *}$ & 0.002 & $\begin{array}{l}3>4 \\
2>4\end{array}$ \\
\hline & $\mathrm{V} 4$ & Level 0 - adopsi e-mail & 4.00 & 3.38 & 3.04 & 2.61 & $7.04^{* *}$ & 0.002 & $\begin{array}{l}1>4 \\
2>4\end{array}$ \\
\hline \multirow{3}{*}{$\begin{array}{l}\text { Tingkat } \\
\text { Penggunaan } \\
\text { Internet }\end{array}$} & V5 & $\begin{array}{l}\text { Level } 1 \text { - Kehadiran } \\
\text { Internet }\end{array}$ & 3.04 & 2.74 & 2.57 & 2.26 & $3.90^{* *}$ & 0.009 & $2>4$ \\
\hline & V6 & Level 2 - Pencarian & 4.60 & 4.56 & 4.49 & 4.38 & 2.01 & 0.59 & - \\
\hline & V7 & Level 3 - integrasi bisnis & 4.71 & 4.63 & 4.51 & 4.42 & 1.09 & 0.29 & - \\
\hline \multirow{8}{*}{ Etika Bisnis } & V8 & $\begin{array}{l}\text { Level } 4 \text { - transformasi } \\
\text { bisnis }\end{array}$ & 5.43 & 4.29 & 5.19 & 5.13 & 2.23 & 0.32 & - \\
\hline & V9 & $\begin{array}{l}\text { Independensi dan } \\
\text { objektivitas }\end{array}$ & 5.88 & 5.47 & 5.44 & 5.33 & 2.04 & 0.11 & - \\
\hline & V10 & $\begin{array}{l}\text { Kerahasiaan dan } \\
\text { kejujuran }\end{array}$ & 5.54 & 5.39 & 5.41 & 5.30 & 1.76 & 0.52 & - \\
\hline & V11 & $\begin{array}{l}\text { Transparansi dan } \\
\text { Integritas. }\end{array}$ & 4.40 & 4.32 & 4.24 & 4.20 & 1.08 & 0.19 & - \\
\hline & V12 & Pengurangan Biaya & 4.57 & 4.36 & 4.26 & 4.20 & 2.01 & 0.49 & - \\
\hline & V13 & $\begin{array}{l}\text { Inovasi dan } \\
\text { pembaharuan }\end{array}$ & 4.30 & 4.26 & 4.19 & 4.06 & 1.09 & 0.39 & - \\
\hline & V14 & Diferensiasi & 4.88 & 4.54 & 4.67 & 4.52 & 2.39 & 0.43 & - \\
\hline & V15 & Pengurangan biaya. & 3.88 & 3.54 & 3.67 & 3.52 & 1.39 & 0.47 & - \\
\hline \multirow{4}{*}{ Daya Saing } & V16 & Inovasi & 4.78 & 4.64 & 4.57 & 4.42 & 2.27 & 0.32 & - \\
\hline & V17 & Pertumbuhan & 4.87 & 4.56 & 4.47 & 4.32 & 2.19 & 0.37 & - \\
\hline & V18 & Persekutuan & & & & & & & $1>2$ \\
\hline & & & 4.81 & 4.38 & 4.38 & 4.35 & $3.43^{*}$ & 0.018 & $\begin{array}{l}1>3 \\
1>4\end{array}$ \\
\hline
\end{tabular}

Sumber : data hasil penelitian (diolah).

${ }^{*} \mathrm{\alpha}<0.05,{ }^{* *} \mathrm{\alpha}<0.01,{ }^{* * *} \mathrm{\alpha}<0.001$.

\section{Analisis Varians Tingkat Pendidikan}

Rata-rata tingkat pendidikan Manajer UMKM di Pamekasan terdiri dari lulusan SMP, SMA, dan S-1. Perbedaan varians untuk sebagian indikator signifikan. Hasil Scheffe's test menunjukkan bahwa 3 indikator dari variabel Faktor Kontingensi yaitu Strategi teknologi bisnis, Dukungan manajemen puncak dan Kompatibilitas Teknologi menunjukkan tingkat pendidikan yang tinggi cenderung lebih tinggi dalam mem- berikan perhatian terkait Faktor Kontingensi. Dan juga indikator untuk tingkat pendidikan Independensi dan objektivitas adalah signifikan dengan perbandingan tingkat pendidikan S1 lebih tinggi dari pada SMP dan SMA, dan pendidikan SMA lebih tinggi dari pada SMP dalam memberikan perhatian terkait indikator Independensi dan objektivitas.

Tabel 11 menunjukkan keseluruhan hasil tes ANOVA. 
Tabel 11

Hasil ANOVA untuk Tingkat Pendidikan

\begin{tabular}{|c|c|c|c|c|c|c|c|c|}
\hline \multirow[b]{2}{*}{ Variable } & \multirow[b]{2}{*}{$\begin{array}{l}\text { Code } \\
\text { Name }\end{array}$} & \multirow[b]{2}{*}{ Indicators } & \multicolumn{3}{|c|}{ Rata-rata Pendidikan } & \multirow[b]{2}{*}{$\begin{array}{c}\text { F } \\
\text { Value }\end{array}$} & \multirow[b]{2}{*}{$\begin{array}{c}\mathbf{P} \\
\text { Value }\end{array}$} & \multirow[b]{2}{*}{$\begin{array}{c}\text { Scheffe's } \\
\text { Test }\end{array}$} \\
\hline & & & $\begin{array}{l}\text { SMP } \\
\text { (1) }\end{array}$ & $\begin{array}{c}\text { SMA } \\
(2)\end{array}$ & $\begin{array}{l}\text { S1 } \\
(3)\end{array}$ & & & \\
\hline \multirow{3}{*}{$\begin{array}{c}\text { Faktor } \\
\text { Kontingensi }\end{array}$} & V1 & Strategi teknologi bisnis & 5.14 & 5.31 & 5.83 & $14.62^{* * *}$ & $<.0001$ & $\begin{array}{l}3>2 \\
3>1 \\
2>1\end{array}$ \\
\hline & $\mathrm{V} 2$ & $\begin{array}{l}\text { Dukungan manajemen } \\
\text { puncak }\end{array}$ & 4.24 & 4.31 & 4.80 & $8.22^{* *}$ & 0.004 & $\begin{array}{l}3>2 \\
3>1\end{array}$ \\
\hline & V3 & Kompatibilitas Teknologi & 5.56 & 5.91 & 6.05 & $20.31^{* * *}$ & $<.0001$ & $\begin{array}{l}3>1 \\
2>1\end{array}$ \\
\hline \multirow{5}{*}{$\begin{array}{c}\text { Tingkat } \\
\text { Penggunaan } \\
\text { Internet }\end{array}$} & $\mathrm{V} 4$ & \multirow{5}{*}{$\begin{array}{l}\text { Level } 0 \text { - adopsi e-mail } \\
\text { Level } 1 \text { - Kehadiran } \\
\text { Internet } \\
\text { Level } 2 \text { - Pencarian } \\
\text { Level } 3 \text { - integrasi bisnis } \\
\text { Level } 4 \text { - transformasi } \\
\text { bisnis }\end{array}$} & 4.96 & 4.80 & 4.72 & 2.16 & 0.61 & - \\
\hline & V5 & & 5.39 & 5.30 & 5.21 & 1.96 & 0.14 & - \\
\hline & V6 & & 4.36 & 4.30 & 4.42 & 1.17 & 0.31 & - \\
\hline & V7 & & 5.36 & 5.30 & 5.42 & 2.17 & 0.51 & - \\
\hline & V8 & & 3.76 & 3.60 & 3.52 & 2.14 & 0.31 & - \\
\hline \multirow{5}{*}{ Etika Bisnis } & V9 & $\begin{array}{l}\text { Independensi dan } \\
\text { objektivitas }\end{array}$ & 5.11 & 5.49 & 6.00 & $13.15^{\star * *}$ & $<.0001$ & $\begin{array}{l}3>2 \\
3>1 \\
2>1\end{array}$ \\
\hline & V10 & Kerahasiaan dan kejujuran & 2.77 & 2.60 & 2.40 & 2.09 & 0.13 & - \\
\hline & V11 & $\begin{array}{l}\text { Transparansi dan } \\
\text { Integritas. }\end{array}$ & 5.54 & 5.42 & 5.45 & 0.84 & 0.43 & - \\
\hline & V12 & Pengurangan Biaya & 4.76 & 4.60 & 4.52 & 2.17 & 0.81 & - \\
\hline & V13 & Inovasi dan pembaharuan & 4.96 & 4.80 & 4.72 & 1.57 & 0.51 & - \\
\hline & $\begin{array}{l}\text { V14 } \\
\text { V15 }\end{array}$ & $\begin{array}{l}\text { Diferensiasi } \\
\text { Pengurangan biaya. }\end{array}$ & 5.76 & 5.60 & 5.52 & 1.17 & 0.61 & - \\
\hline Daya Saing & V16 & Inovasi & 5.80 & 5.94 & 6.00 & 2.61 & 0.53 & - \\
\hline & V17 & Pertumbuhan & 3.77 & 3.60 & 3.40 & 3.09 & 0.33 & - \\
\hline & V18 & Persekutuan & 2.76 & 2.60 & 2.52 & 2.18 & 0.61 & - \\
\hline
\end{tabular}

Sumber : data hasil penelitian (diolah).

* $\mathrm{a}<0.05,{ }^{* *} \mathrm{a}<0.01,{ }^{* * *} \mathrm{\alpha}<0.001$.

\section{Analisis varians Rentang Waktu}

Rentang Waktu berjalannya UMKM di pamekasan terdiri dari tiga kelompok yaitu di bawah 10 tahun, antara 11 sampai 15 tahun, dan di atas 16 tahun. Hasil analisis varians hanya dua indikator yang dipengaruhi oleh Rentang Waktu yaitu Kompatibilitas Teknologi dan Level 0 adopsi e-mail dengan perbandingan yaitu UMKM yang beroprasi dibawah 10 tahun secara sginifikan lebih tinggi dari pada yang beroprasi di atas 16 tahun. Dan UMKM yang beroperasi, antara 11 sampai 15 tahun secara sginifikan lebih tinggi dari pada yang beroperasi di atas 16 tahun. Hasil Scheffe's test untuk kedua indikator tersebut yaitu UMKM yang lebih muda cenderung lebih memberikan perhatian terkait Kompatibilitas Teknologi dan Level 0 adopsi e-mail. Hal itu bisa dilihat pada Tabel 12.

\section{Analisis Varians Tingkat Pendapatan}

Penelitian ini juga menguji perbedaan tingkat pendapatan terhadap masing-masing variabel yang diamati. Variabel tingkat pendapatan pada UMKM di pamekasan terdiri dari tiga kelompok yaitu di atas 60 juta rupiah, antara 61 sampai 180 juta rupiah, di atas atau antara 181 juta rupiah. Hasil Scheffe's test menunjukkan bahwa tingkat pendapatan yang lebih tinggi pada UMKM cenderung lebih memberikan perhatian 
yang lebih tinggi terkait Strategi teknologi bisnis dan Dukungan manajemen puncak.
Tabel 13 menunjukkan hasil test ANOVA untuk keseluruhan tingkat pendapatan.

Tabel 12

Hasil test ANOVA untuk Rentang Waktu

\begin{tabular}{|c|c|c|c|c|c|c|c|c|}
\hline \multirow[b]{2}{*}{ Variabel } & \multirow[b]{2}{*}{$\begin{array}{l}\text { Nama } \\
\text { kode }\end{array}$} & \multirow[b]{2}{*}{ Indikator } & \multicolumn{3}{|c|}{$\begin{array}{c}\text { Rentang Waktu } \\
\text { (tahun) }\end{array}$} & \multirow[b]{2}{*}{$\begin{array}{c}\text { F } \\
\text { Value }\end{array}$} & \multirow[b]{2}{*}{$\begin{array}{c}\mathbf{P} \\
\text { Value }\end{array}$} & \multirow[b]{2}{*}{$\begin{array}{c}\text { Scheffe's } \\
\text { Test }\end{array}$} \\
\hline & & & $\begin{array}{c}\leq 10 \\
(1)\end{array}$ & $\begin{array}{l}11-15 \\
(2)\end{array}$ & $\begin{array}{l}\geq 16 \\
(3)\end{array}$ & & & \\
\hline \multirow{3}{*}{$\begin{array}{c}\text { Faktor } \\
\text { Kontingensi }\end{array}$} & V1 & Strategi teknologi bisnis & 5.39 & 5.30 & 5.21 & 1.96 & 0.14 & - \\
\hline & V2 & $\begin{array}{l}\text { Dukungan manajemen } \\
\text { puncak }\end{array}$ & 4.36 & 4.30 & 4.42 & 1.17 & 0.31 & - \\
\hline & V3 & Kompatibilitas Teknologi & 5.89 & 5.88 & 5.66 & $4.19^{*}$ & 0.02 & $\begin{array}{l}1>3 \\
2>3\end{array}$ \\
\hline \multirow{5}{*}{$\begin{array}{l}\text { Tingkat } \\
\text { Penggunaan } \\
\text { Internet }\end{array}$} & $\mathrm{V} 4$ & Level 0 - adopsi e-mail & 3.46 & 3.12 & 2.74 & $4.76^{* *}$ & 0.0095 & $1>3$ \\
\hline & V5 & $\begin{array}{l}\text { Level } 1 \text { - Kehadiran } \\
\text { Internet }\end{array}$ & 5.80 & 5.94 & 6.00 & 1.61 & 0.34 & - \\
\hline & V6 & Level 2 - Pencarian & 2.36 & 2.30 & 2.42 & 1.27 & 0.41 & - \\
\hline & V7 & Level 3 - integrasi bisnis & 3.60 & 3.61 & 3.61 & 0.32 & 0.91 & - \\
\hline & V8 & $\begin{array}{l}\text { Level } 4 \text { - transformasi } \\
\text { bisnis }\end{array}$ & 2.77 & 2.60 & 2.40 & 2.09 & 0.13 & - \\
\hline \multirow{5}{*}{ Etika Bisnis } & V9 & $\begin{array}{l}\text { Independensi dan } \\
\text { objektivitas }\end{array}$ & 5.54 & 5.42 & 5.45 & 0.84 & 0.43 & - \\
\hline & V10 & Kerahasiaan dan kejujuran & 4.48 & 4.37 & 4.46 & 1.75 & 0.15 & - \\
\hline & V11 & $\begin{array}{l}\text { Transparansi dan } \\
\text { Integritas. }\end{array}$ & 4.95 & 4.86 & 4.77 & 1.64 & 0.28 & - \\
\hline & V12 & Pengurangan Biaya & 2.45 & 2.36 & 2.47 & 1.84 & 0.58 & - \\
\hline & V13 & Inovasi dan pembaharuan & 5.49 & 5.35 & 5.46 & 2.45 & 0.88 & - \\
\hline \multirow{5}{*}{ Daya Saing } & V14 & Diferensiasi & 4.60 & 4.61 & 4.61 & 0.01 & 0.99 & - \\
\hline & V15 & Pengurangan biaya. & 4.49 & 4.35 & 4.46 & 2.40 & 0.78 & - \\
\hline & V16 & Inovasi & 3.77 & 3.60 & 3.40 & 1.09 & 0.13 & - \\
\hline & V17 & Pertumbuhan & 5.60 & 5.61 & 5.61 & 0.84 & 0.49 & - \\
\hline & V18 & Persekutuan & 4.45 & 4.36 & 4.47 & 1.74 & 0.18 & - \\
\hline
\end{tabular}

Sumber : data hasil penelitian (diolah).

* $\mathrm{\alpha}<0.05,{ }^{* *} \mathrm{\alpha}<0.01, * * * \mathrm{\alpha}<0.001$.

Tabel 13

Hasil Tingkat Pendapatan

\begin{tabular}{|c|c|c|c|c|c|c|c|c|}
\hline \multirow{2}{*}{ Variable } & \multirow{2}{*}{$\begin{array}{l}\text { Code } \\
\text { Name }\end{array}$} & \multirow{2}{*}{ Indicators } & \multicolumn{3}{|c|}{$\begin{array}{l}\text { Level Pendapatan } \\
\text { (dalam jutaan Rp) }\end{array}$} & \multirow{2}{*}{$\begin{array}{c}\text { F } \\
\text { Value }\end{array}$} & \multirow{2}{*}{$\begin{array}{c}P \\
\text { Value }\end{array}$} & \multirow{2}{*}{$\begin{array}{c}\text { Scheffe's } \\
\text { Test }\end{array}$} \\
\hline & & & $\begin{array}{l}\leq 60 \\
(1)\end{array}$ & $\begin{array}{l}61-180 \\
(2)\end{array}$ & $\begin{array}{l}\geq 181 \\
\quad(3)\end{array}$ & & & \\
\hline \multirow{4}{*}{$\begin{array}{c}\text { Faktor } \\
\text { Kontingensi }\end{array}$} & V1 & $\begin{array}{l}\text { Strategi teknologi } \\
\text { bisnis }\end{array}$ & 5.15 & 5.46 & 5.83 & $17.87^{* * *}$ & $<.0001$ & $\begin{array}{l}3>1 \\
2>1\end{array}$ \\
\hline & V2 & $\begin{array}{l}\text { Dukungan manajemen } \\
\text { puncak }\end{array}$ & 4.17 & 4.46 & 4.89 & $15.12^{* * *}$ & $<.0001$ & $\begin{array}{l}3>1 \\
2>1\end{array}$ \\
\hline & V3 & $\begin{array}{l}\text { Kompatibilitas } \\
\text { Teknologi }\end{array}$ & 5.80 & 5.94 & 6.00 & 1.60 & 0.74 & - \\
\hline & $\mathrm{V} 4$ & Level 0 - adopsi e-mail & 4.54 & 4.42 & 4.45 & 1.74 & 0.63 & - \\
\hline \multirow{3}{*}{$\begin{array}{c}\text { Tingkat } \\
\text { Penggunaan } \\
\text { Internet }\end{array}$} & V5 & $\begin{array}{l}\text { Level } 1 \text { - Kehadiran } \\
\text { Internet }\end{array}$ & 2.77 & 2.60 & 2.40 & 2.09 & 0.13 & - \\
\hline & V6 & Level 2 - Pencarian & 5.54 & 5.42 & 5.45 & 0.84 & 0.43 & - \\
\hline & V7 & $\begin{array}{l}\text { Level } 3 \text { - integrasi } \\
\text { bisnis }\end{array}$ & 4.80 & 4.94 & 4.00 & 1.61 & 0.54 & - \\
\hline
\end{tabular}




\begin{tabular}{|c|c|c|c|c|c|c|c|c|}
\hline & V8 & $\begin{array}{l}\text { Level } 4 \text { - transformasi } \\
\text { bisnis }\end{array}$ & 5.80 & 5.94 & 5.00 & 1.71 & 0.84 & - \\
\hline \multirow{5}{*}{ Etika Bisnis } & V9 & $\begin{array}{l}\text { Independensi dan } \\
\text { objektivitas }\end{array}$ & 4.54 & 4.42 & 4.45 & 0.44 & 0.53 & - \\
\hline & V10 & $\begin{array}{l}\text { Kerahasiaan dan } \\
\text { kejujuran }\end{array}$ & 5.99 & 5.88 & 5.77 & 0.66 & 0.35 & - \\
\hline & V11 & $\begin{array}{l}\text { Transparansi dan } \\
\text { Integritas. }\end{array}$ & 5.70 & 5.64 & 6.50 & 1.41 & 0.44 & - \\
\hline & V12 & Pengurangan Biaya & 3.54 & 3.42 & 3.45 & 1.84 & 0.83 & - \\
\hline & V13 & $\begin{array}{l}\text { Inovasi dan } \\
\text { pembaharuan }\end{array}$ & 5.59 & 5.48 & 5.47 & 0.86 & 0.45 & - \\
\hline \multirow{5}{*}{ Daya Saing } & V14 & Diferensiasi & 3.94 & 3.82 & 3.75 & 1.64 & 0.53 & - \\
\hline & V15 & Pengurangan biaya. & 2.54 & 2.42 & 2.45 & 0.34 & 0.23 & - \\
\hline & V16 & Inovasi & 4.80 & 4.94 & 4.00 & 1.61 & 0.54 & - \\
\hline & V17 & Pertumbuhan & 5.70 & 5.64 & 6.50 & 1.41 & 0.64 & - \\
\hline & V18 & Persekutuan & 4.20 & 4.58 & 4.92 & 0.34 & 0.23 & - \\
\hline
\end{tabular}

Sumber : data hasil penelitian (diolah).

* $\mathrm{a}<0.05, * * \mathrm{a}<0.01, * * * \mathrm{a}<0.001$.

\section{Pembahasan Hasil Penelitian}

Faktor kontingensi berpengaruh positif pada Tingkat Penggunaan Internet $\left(\mathrm{H}_{1}\right.$ diterima).

Temuan pada penelitian ini yaitu faktor kontingensi berpengaruh positif dan signifikan terhadap tingkat penggunaan internet, hal itu di buktikan dengan diperolehnya nilai koefisien yaitu 0,99 , dan nilai $\mathrm{t}$ yaitu 25,60 , dengan nilai p yaitu $<0,001$. temuan pada penelitian ini adalah sama dengan temuan penelitian yang dilakukan Teo dan Pian (2003), sehingga dapat disimpulkan faktor kontingensi berpengaruh positif dam signifikan terhadap tingkat penggunaan internet. Artinya pihak UMKM harus betulbetul memperhatikan pentingnya pengaruh dari faktor kontingensi dalam meningkatkan tingkat penggunaan internet.

Penggunaan internet berpengaruh positif terhadap Daya saing $\left(\mathrm{H}_{2}\right.$ diterima $)$.

Temuan pada penelitian ini membuktikan bahwa Tingkat Penggunaan internet berpengaruh positif dan signifikan terhadap Daya Saing, hal tersebut ditunjukkan dengan nilai koefisien sebesar 0,48 , dan nilai $\mathrm{t}$ sebesar 11,20 , serta nilai $p$ yaitu $<0,001$. Pian (2003) melakukan penelitian dengan hasil yang menyebutkan bahwa Tingkat Penggunaan internet adalah penting untuk diperhatikan demi tercapainya Daya Saing, dan penelitian tersebut sesuai dengan hasil penelitian ini.

Etika Bisnis berpengaruh positif terhadap Daya Saing $\left(\mathrm{H}_{3}\right.$ diterima).

Hasil analisis data menunjukkan nilai koefisien yaitu 0,39 , nilai t yaitu 7.80 , dan nilai $p$ yaitu $<0,001$. Hasil tersebut menunjukkan bahwa Etika Bisnis memiliki peran penting terhadap Daya Saing. Kasasbeh et al. (2014) menyimpulkan Etika Bisnis memiliki dampak positif terhadap Daya Saing. Temuan tersebut adalah sama dengan penelitian ini. jadi dapat disimpulkan bahwa Etika Bisnis memainkan peran penting terhadap Daya Saing.

Analisis varians variabel demografi pada masing-masing variabel $\left(\mathrm{H}_{4}\right.$ diterima secara parsial)

Dalam penelitian ini, analisis varians (ANOVA) adalah untuk menganalisis pengaruh variabel demografi pada masingmasing variabel. Variabel demografi terdiri dari jenis kelamin, jenis UMKM, umur pengusaha, tingkat pendidikan, tingkat kepemilikan, dan tingkat pendapatan. Variabel yang diamati yang pertama yaitu Faktor Kontingensi yang terdiri dari Dukungan manajemen puncak, Kompatibilitas Teknologi dan Strategi teknologi bisnis, variabel yang kedua yaitu Tingkat Penggunaan Internet 
yang terdiri dari tingkat 0 penggunaan email, Tingkat 1 Keberadaan Internet, Tingkat 2 Pencarian, Tingkat 3 integrasi bisnis, Tingkat 4 transformasi bisnis, variabel yang ketiga yaitu Etika Bisnis yang terdiri dari Inovasi dan pembaharuan, Transparansi dan Integritas, Pengurangan Biaya, Independensi dan objektivitas dan Kerahasiaan dan kejujuran, dan variabel yang keempat yaitu Daya Saing yang terdiri dari Inovasi, Pengurangan biaya, Persekutuan, Diferensiasi dan Pertumbuhan.

Analisis varians jenis kelamin pada masing-masing variabel

Temuan dalam penelitian ini yaitu ada perbedaan pengaruh yang signifikan antara pria dan wanita. hal tersebut menunjukkan bahwa hubungan antara jenis kelamin pria dan wanita manajer UMKM tidaklah sama dalam UMKM.

\section{Analisis variansi jenis UMKM pada masing-masing variabel}

Tipe fashion secara signifikan lebih tinggi daripada jenis kerajinan, dan jenis kerajinan lebih tinggi daripada jenis makanan pada semua indikator dari variabel Faktor.

Tipe fashion secara signifikan lebih tinggi daripada jenis kerajinan, dan jenis kerajinan lebih tinggi daripada jenis makanan pada dua indikator dari Tingkat Penggunaan Internet yaitu Level 0 adopsi e-mail dan Level 1 Kehadiran Internet.

Tipe fashion secara signifikan lebih tinggi daripada jenis kerajinan dan jenis makanan pada dua indikator dari Etika Bisnis yaitu Independensi dan objektivitas dan tipe fashion secara signifikan lebih tinggi daripada jenis kerajinan, dan jenis kerajinan lebih tinggi daripada jenis makan an pada indikator Kerahasiaan dan kejujuran.

Analisis variansi umur pada masingmasing variabel

Kelompok umur dengan rentang 41-50 tahun secara signifikan lebih tinggi daripada di atas 50 tahun. Dan kelompok umur dengan rentang 31-40 tahun secara signifikan lebih tinggi daripada umur di atas 50 tahun pada indikator Kompatibilitas Teknologi.

Kelompok umur dengan rentang $\leq 30$ secara signifikan lebih tinggi daripada umur di atas 50 tahun pada indikator Level 0 adopsi e-mail .

Kelompok umur dengan rentang 31-40 secara signifikan lebih tinggi daripada umur di atas 50 tahun pada indikator Level 1 Kehadiran Internet.

Kelompok umur dengan rentang $\leq 30$ secara signifikan lebih tinggi daripada umur 31-40, 41-50 dan umur di atas 50 tahun pada indikator Persekutuan.

\section{Analisis varians tingkat pendidikan pada} masing-masing variabel.

Secara signifikan tingkat pendidikan yang tinggi cenderung lebih tinggi dalam memberikan perhatian terkait Faktor Kontingensi yaitu Dukungan manajemen puncak, kompatibilitas Teknologi dan trategi teknologi bisnis.

Secara signifikan tingkat pendidikan S1 lebih tinggi dari pada SMP dan SMA, dan pendidikan SMA lebih tinggi dari pada SMP dalam memberikan perhatian terkait indikator Independensi dan objektivitas.

Analisis variansi tingkat rentang waktu operasi UMKM pada masing-masing variabel

UMKM yang lebih muda secara signifikan cenderung lebih memberikan perhatian terkait Kompatibilitas Teknologi dan Level 0 adopsi e-mail.

Analisis varians tingkat pendapatan pada masing-masing variabel

Tingkat pendapatan yang lebih tinggi pada UMKM secara signifikan cenderung lebih memberikan perhatian yang lebih tinggi terkait Strategi teknologi bisnis dan Dukungan manajemen puncak.

\section{SIMPULAN DAN SARAN} Simpulan 
Simpulan penelitian ini yaitu Faktor Kontingensi memiliki dampak positif terhadap Tingkat Penggunanaa Internet. Tingkat Penggunanaa Internet memiliki dampak positif terhadap Daya Saing. dan Etika Bisnis memiliki dampak positif terhadap Daya Saing dan Variabel Demografi memiliki perbedaan pengaruh yang signifikan terhadap masing-masing variabel.

\section{Keterbatasan dan Saran}

Seiring adanya perubahan dalam lingkungan bisnis serta adanya temuan penelitian terdahulu, maka sangat mungkin peran dari Faktor Kontingensi, Tingkat Penggunaan Internet, Etika Bisnis terhadap Daya Saing dapat berubah dari waktu ke waktu. Beriktibar pada penelitian sebelumnya, maka pada penelitian ini terdapat batasan serta saran untuk penelitian selanjutnya. Batasannya yaitu penelitian ini hanya berfokus pada kegiatan UMKM di kabupaten Pamekasan saja, sehingga temuan dari penelitian ini tidak dapat digeneralisasikan selain kepada UMKM. oleh karena fokus dari penelitian ini terkait UMKM di kabupaten Pamekasan. maka Penelitian yang akan datang bisa menganalisis perusahaan yang lebih besar di kabupaten lainnya sehingga dapat lebih memperluas hasil penelitian. Tujuan dari penelitian ini untuk menggali secara detail Peran serta Faktor Kontingensi, Tingkat Penggunaan Internet, Etika Bisnis dalam jangka waktu tertentu serta pengaruhnya terhadap Daya Saing. Namun, pengaruh beberapa variabel mungkin berubah seiring berjalannya waktu sehingga membuat hasilnya mungkin tidak sama. Oleh karena itu, penelitian ini menyarankan agar penelitian selanjutnya dapat mengembangkan model penelitian agar mendapat temuan yang lebih mendalam.

\section{DAFTAR PUSTAKA}

Ahmed, R. dan Mohamad. 2016. Effect of Multidimensional top Management Support on Project Success: an Empirical Investigation. Springer Science Business Media Quality \& Quantity 50(1): 151-176.
Anderson, J. C. \& Gerbing D. W. 1988. Structural equation modeling in practice: a review and recommended two step approach. Psychological Bullentin, 103: 411-423.

Badan Pusat Statistik Kabupaten Pamekasan. 2010-2014. Produk Domestik Regional Bruto Kabupaten Pamekasan Menurut Pengeluaran. BPS Kabupaten Pamekasan.

Bentler, P. M. dan C. P. Chou. 1987. Practical Issues in Structural Modeling. Sociological Methods and Research 16(1): 78-117.

Chamsuk, W., T. Phimonsathien, dan W. Fongsuwan. 2015. Research Development (R\&D) Capabilities And Innovation Capability That Affect The Enterprise Competitive Advantage In The Thai Automotive Parts Industry: SEM Approach. International Journal of Arts $\mathcal{E}$ Sciences 08(02): 441-457.

Chang, C. H. 2011. The Influence of Corporate Environmental Ethics on Competitive Advantage: The Mediation Role of Green Innovation. Journal of Business Ethics 104(3): 361-370.

Chen, Y. S. 2008. The Positive Effect of Green Intellectual Capital on Competitive Advantages of Firms. Journal of Business Ethics 77(3): 271-286.

Chen, Y. S., S. B. Lai, dan C. T. Wen. 2006. The Influence of Green Innovation Performance on Corporate Advantage in Taiwan. Journal of Business Ethics 67(4): 331-339.

Hazen, B. T. dan T. A. Byrd. 2012. Toward Creating Competitive Advantage with Logistics Information Technology. International Journal of Physical Distribution \& Logistics Management 42(1): 8-35.

Hernandez, B., J. Jimenez, dan J. M. Martin. 2008. Business Acceptance of Information Technology: Expanding TAM using Industry Sector and Technological Compatibility. International Journal of Enterprise Information Systems (IJEIS) 4(4): 5-18.

Hooper, D., J. Coughlan, dan M. R. Mullen. 2008. Structural Equation Modelling: Guidelines for Determining Model Fit. 
The Electronic Journal of Business Research Methods 6(1): 53-60.

Huang, X., T. F. Gattiker, dan R. G. Schroeder. 2010. Do Competitive Priorities Drive Adoption of Electronic Commerce Aplications? Testing the Cintingency and Institutional Views. Journal of Supply Chain Management 46(3): 57-69.

Jiménez-Jiménez, D. \& Sanz-Valle R. 2011. Innovation, organizational learning, and performance. Journal of Business Research, 64(4), 408-417.

Kannabiran, G. 2012. Enablers and Inhibitors of Advanced Information Technologies Adoption by SMEs an Empirical Study of Auto Ancillaries in India. Journal of Enterprise Information Management 25(2): 186-209.

Kaplan, D. 2000. Structural Equation Modeling Foundation and Extensions. Sage publication. London.

Kasasbeh, E. A., Y. Harada, A. B. Osman, dan B. O. Aldalayeen. 2014. The Impact Of Business Ethics In The Competitive Advantage (In The Cellular Communications Companies Operating In Jordan). European Scientific Journal 10(10): 269-284.

Kearns, G. S. dan A. L. Lederer. 2003. A Resource-Based View of Strategic IT Alignment: How Knowledge Sharing Creates Competitive Advantage. Decision Sciences 34(1): 1-29.

Kementerian Koperasi dan UMKM. 2014. Perkembangan UMKM di Indonesia. Kementerian Koperasi dan UMKM.

Lai, F., X. Zhao, dan Q. Wang. 2006. The Impact of Information Technology on the Competitive Advantage of Logistics Firms in China. Industrial Management $\mathcal{E}$ Data Systems 106(9): 1249-1271.

MacCallum, R. C., M. W. Browne, dan H. M. Sugawara. 1996. Power Analysis and Determination of Sample Size for Covariance Structure Modeling. Psychological methods 1(2): 130-149.
Morabito, V., M. Themistocleous, dan A. Serrano. 2010. A Survey on Integrated IS and Competitive Advantage. Journal of Enterprise Information Management 23(2): 201-214.

Raymond, L. dan F. Bergeron. 2008. Enabling the Business Strategy of SMEs through E-business Capabilities: a Strategic Alignment Perspective. Industrial Management $\mathcal{E}$ Data Systems 108(5): 577-595.

Saeed, M. M. dan F. Arshad. 2012. Corporate Social Responsibility as a Source of Competitive Advantage: The Mediating Role of Social Capital and Reputational Capital. Journal of Database Marketing $\mathcal{E}$ Customer Strategy Management 19(4): 219232.

Schumacker, R. E., \& Lomax, R. G. 2004. A beginner's guide to structural equation modeling, Second edition. Mahwah, NJ: Lawrence Erlbaum Associates.

Simmons, G. J., M. G. Durkin, P. McGowan, dan G. A. Armstrong. 2007. Determinants of Internet Adoption by SME Agrifood Companies. Journal of Small Business and Enterprise Development 14(4): 620-640.

Swimm, N. dan S. J. Andriole. 2010. Business Tehnology Strategy for an Energy Management Company. Journal of Information Tehnology Research (JITR) 3(3): 5-12.

Taleb, A. 2015. A Framework for Knowledge Sharing, Firm Innovation Capability and Competitive Advantage in the U.A.E. Academic Conferences International Limited: 879-886.

Teo, T. dan Y. Pian. 2003. A Contingency Perspective on Internet Adoption and Competitive Advantage. European Journal of Information Systems 12(2): 7892.

Tian, J., K. Wang, dan Y. Chen. 2010. From IT Deployment Capabilities to Competitive Advantage: an Exploratory Study in China. Information Systems Frontiers 12(3): 239-255. 